\title{
Renaissance of armored immune effector cells, CAR-NK cells, brings the higher hope for successful cancer therapy
}

\author{
Faroogh Marofi ${ }^{1}{ }^{2}$, Heshu Sulaiman Rahman ${ }^{3}$, Lakshmi Thangavelu $^{4}$, Aleksey Dorofeev ${ }^{5}$, Favian Bayas-Morejón ${ }^{6}$, \\ Naghmeh Shirafkan ${ }^{2}$, Navid Shomali ${ }^{2}$, Max Stanley Chartrand ${ }^{7}$, Mostafa Jarahian ${ }^{8}$, Ghasem Vahedi ${ }^{9}$, \\ Rebar N. Mohammed ${ }^{10}$, Somayeh Shahrokh ${ }^{11}$, Morteza Akbari ${ }^{2}$ and Farhad Motavalli Khiavi ${ }^{12^{*}}$
}

\begin{abstract}
In recent decades, a new method of cellular immunotherapy was introduced based on engineering and empowering the immune effector cells. In this type of immunotherapy, the immune effector cells are equipped with chimeric antigen receptor (CAR) to specifically target cancer cells. In much of the trials and experiments, CARmodified T cell immunotherapy has achieved very promising therapeutic results in the treatment of some types of cancers and infectious diseases. However, there are also some considerable drawbacks in the clinical application of CAR-T cells although much effort is in progress to rectify the issues. In some conditions, CAR-T cells initiate overactivated and strong immune responses, therefore, causing unexpected side-effects such as systemic cytokine toxicity (i.e., cytokine release syndrome), neurotoxicity, on-target, off-tumor toxicity, and graft-versus-host disease (GvHD). To overcome these limitations in CAR-T cell immunotherapy, NK cells as an alternative source of immune effector cells have been utilized for CAR-engineering. Natural killer cells are key players of the innate immune system that can destroy virus-infected cells, tumor cells, or other aberrant cells with their efficient recognizing capability. Compared to T cells, CAR-transduced NK cells (CAR-NK) have several advantages, such as safety in clinical use, non-MHC-restricted recognition of tumor cells, and renewable and easy cell sources for their preparation. In this review, we will discuss the recent preclinical and clinical studies, different sources of NK cells, transduction methods, possible limitations and challenges, and clinical considerations.
\end{abstract}

Keywords: CAR, NK cells, T cells, Immunotherapy

\section{Introduction}

As we expand our knowledge and understanding of how the immune system acts against cancer, we are more likely to believe in the immune system's power. Therefore, in recent decades, we relied more on novel immune-based therapies than the classic chemical drugs (chemotherapies) to treat cancer. Various novel immunotherapy methods are in development to achieve effective and durable therapies for patients with hardly

\footnotetext{
* Correspondence: farhad.motavalli@gmail.com

${ }^{12}$ Department of Virology, Pasteur Institute of Iran (IPI), Tehran, Iran

Full list of author information is available at the end of the article
}

treatable or refractory cancers [1]. Cancer immunotherapy exploits the body's immune system to fight against cancer and is classified by three branches: immune checkpoint inhibitors (ICIs), adoptive cell therapies (ACTs), and tumor vaccines [2, 3]. Cancer immunotherapy can help patients with advanced tumors or recurrent cancers [4].

ICIs block the checkpoint receptors/ligands on immune cells and cancer cells then prompt the killing mechanisms in immune effector cells. This type of immunotherapy was found to be advantageous in various malignancies, e.g., Hodgkin's lymphoma [5, 6]. ICIs have 
gained much attention over the past years for their great therapeutic potential in various cancers. Several ICIs have been investigated or are being tested. Novel therapeutic antibodies have been developed relying on NK cell-based ICI such as Lirilumab, Monalizumab, Lacutamab, Etigilimab, Tiragulomab, Relatlimab, Eftilagimod alpha, Cobolimab, Samalizumab, Magrolimab, Ipilimumab, Nivolumab, Pembrolizumab, Atezolizumab, Durvalumab, Avelumab, Dostarlimab, Spartalizumab, Tislelizumab, Lodapolimab, Enoblituzumab, Orlotamab, and many other developed/under development therapies [7-10]. The inhibitory receptors on NK cells with promising potential to develop ICIs are classical NK cell receptors KIRs, LIRs, and NKG2A. There are also some other important ICIs such as CTLA-4, PD-1, and recently determined B7-H3, and LAG-3, TIGIT and CD96, TIM-3, and recently characterized checkpoint-members of the Siglecs family (Siglec-7/9), CD200 and CD47. Blocking these ICIs on NK cells push the balance of activation-inhibition of NK cells toward activation due to lack of inhibitory signals. Activated NK cells have substantially more cytolytic/killing power and therefore can detect and attack cancer cells more efficiently. The combination of blocking ICIs on NK cells with CARs can lead to a very efficient and cancer-redirected cytolytic activity of CAR-NK cells $[11,12]$.

In addition, $\mathrm{Bi}$ - and tri-specific antibodies as the novel immunotherapy strategy can engage the immune effector cells toward tumor cells by binding simultaneously to both cells. Then, the forced proximity between effector cells and tumor cells causes the release of cytotoxic molecules and apoptosis of tumor cells. This method showed good anticancer activity against several types of non-Hodgkin lymphomas (NHL) such as diffused large $\mathrm{B}$ cell lymphoma (DLBCL) and follicular lymphoma (FL) [13-15].

Also, another branch of immunotherapy is comprised of genetic modification of immune cells as living drugs. The method is currently under investigation for understanding its usefulness in the treatment of different cancers particularly hematological malignancies. The first successful forms of transduced cells with CAR were autologous $\mathrm{T}$ cells capable of targeting CD19-specific antigen expressed on B cell malignant tumor cells [16]. CAR is an engineered receptor protein capable of specific targeting the antigens introduced to the $\mathrm{T}$ cell. Its structure consists of an extracellular antigen recognition domain attached to an intracellular peptide/protein which acts as the intracellular signaling domains [17].

CARs have been successfully utilized in many research and clinical trials to redirect autologous $\mathrm{T}$ cells against lymphoid leukemia and lymphoma [18]. CAR-expressed $\mathrm{T}$ cells directly recognize the CAR-targeted antigen on cancer cells, and then, $\mathrm{T}$ cell activation, the release of cytotoxic molecules, proliferation, cytokine secretion, and immune cells recruitment are triggered spontaneously following the CAR-antigen contact. These types of modified $\mathrm{T}$ cells have demonstrated success in the treatment of hematological cancers, including lymphoma, chronic lymphocytic leukemia, and acute lymphoblastic leukemia (ALL) [17].

Therefore, the clinical application of CAR $\mathrm{T}$ cells has been mainly constrained to CD19-expressing B cell blood cancers [19-24]. Many research has been conducted to explore CAR-T cells' suitability to be utilized in other hematological cancers such as Hodgkin and non-Hodgkin lymphoma, multiple myeloma (MM), and acute myeloid leukemia (AML) [25-27]. Although the efficacy of CAR $\mathrm{T}$ cell therapy has been good in some types of hematological malignancies, it is important to bear in mind that, with over 100 types of cancer, hematological cancers make only a small part of the diagnosed cases with a cancer and are responsible for only $6 \%$ of all reported cancer deaths [28].

CD19-CAR $T$ cell adoptive immunotherapy has achieved successful results in clinical trials in the treatment of ALL and diffuse large B cell lymphoma [29], but there are also substantial disadvantages causing significant side effects such as cytokine release syndrome (CRS), immune hyperactivation, and neurological toxicities [30]. Furthermore, the method has some considerable limitations including the challenges to generate sufficient autologous $\mathrm{T}$ cells for each patient, timeconsuming and sophisticated preparation procedures, and the high preparation costs which altogether make the method not very cost-effective and easily applicable for health care systems [31]. Considering these limitations, NK cell-based immunotherapy has recently come to light as a potential alternative approach because of its strong antitumor efficiency, no need for prior sensitization, easy preparation process, and better safety profiles in terms of CRS and GvHD. Albeit, allogeneic NK cells, in contrast to primary autologous NK cells and NK cell lines still have the risk of triggering GvHD [32-34].

NK cells are a key member of the innate immune system, and while they have some similarities to cytotoxic $\mathrm{T}$ lymphocytes (CTLs) in term of killing features, they have an extra intrinsic capability to detect and kill transformed/mutant cells independent of specific antigen recognition processes indicating MHC-unrestricted cytotoxicity done with the help of a wide range of receptors such as the natural cytotoxicity receptors (NCRs) $[24,35]$. Introducing CAR on the surface of NK cells have shown the potential of CAR-NK cells to be used as off-the-shelf cellular immunotherapy which can be administered instantly as clinically required and could resolve some of the difficulties related to logistics and cost $s$ [31]. Expression of CARs in NK cells may grant these 
cells to more effectively destroy solid tumors that are often more resistant to effector cytotoxic cells in comparison to hematologic cancers (e.g., acute myelogenous leukemia) that are generally more susceptible to NK cell's cytotoxic fucntions. However, the cytotoxic function of CAR-NK cells is not CAR-restricted; in fact, the CAR plays a recognition-enhancer role for NK cells [36, 37].

In this article, we tend to discuss in the field of recent advances in CAR-engineered NK cell immunotherapy, the advantages of using CAR-NK cells toward CAR-T cells, and different sources of NK cells used for CAR manipulations. Also, various transduction methods to introduce CARs into both primary NK cells and NK cell lines regarding increase efficacy have been discussed. Besides, the results of pre-clinical and clinical studies and the strategies for overcoming challenges and improving safety have been summarized.

\section{NK cells: history, subsets, and mechanisms of their function}

Natural killer (NK) cells were first identified in 1975 as a subpopulation of cells that were different from $\mathrm{T}$ and $\mathrm{B}$ lymphocytes $[38,39]$. For a long time, the functions and biology of NK cells were in the shadow of other immune cells [40]. However, great advances in knowing the NK cells' biology have revealed important outlooks of their inherent capacity to kill infected or malignant cells without prior sensitization and human leukocyte antigens (HLA)-restriction [38, 41, 42].

NK cells are innate immune cells that reside in the blood, spleen, liver, lung, bone marrow, and to a lesser extent in lymph nodes [43]. They play crucial roles in the immune hemostasis and immune surveillance of tumor cells $[44,45]$. Human NK cells are typically characterized by a lack of CD3/TCR molecules while expressing the CD56; thus, they are known for a usual $\mathrm{CD}_{56}{ }^{+} \mathrm{CD} 16^{+} \mathrm{CD}^{-}$phenotype. By considering the expression levels of CD56, NK cells are subdivided into two separate subsets; CD56 $6^{\text {bright }}$ and CD56 ${ }^{\mathrm{dim}}$ [46]. CD56 ${ }^{\mathrm{dim}}$ NK cells are almost $90-95 \%$ of NK cells in the peripheral blood $(\mathrm{PB})$ and inflammatory sites and are capable of mediating high cytotoxicity responses [47]. Since $\mathrm{CD} 56^{\mathrm{dim}}$ cells also express $\mathrm{Fc} \gamma$ receptor CD16, they can detect and destroy tumor cells or virus-infected cells covered by antibodies and therefore can initiate antibody-dependent cell-mediated cytotoxicity (ADCC) [48]. In contrast, CD56 $6^{\text {bright }} \mathrm{NK}$ cells are immature and comprise only about $5-15 \%$ of NK cells in PB [49]. CD56 $6^{\text {bright }}$ NK cells are present in secondary lymphoid tissues and are predominantly powerful in cytokine secretion but with limited cytotoxic properties. CD56 $6^{\text {bright }}$ cells have immunoregulatory functions by producing $\mathrm{cy}-$ tokines or chemokines $[50,51]$ such as IL-12, IL-18, and IL-15 [52]. Given the inherent cytotoxic ability of NK cells, they can release abundant cytotoxic molecules such as perforins and granzymes toward target cells. On the other hand, activated NK cells interact with other immune cells such as dendritic cells (DCs), T cells, and $\mathrm{B}$ cells and impress them by secreting various cytokines and chemokines. They can mediate spontaneous cytotoxicity toward abnormal cells and rapidly secrete immune-regulating cytokines such as IFN- $\gamma$, TNF- $\alpha$, and GM-CSF. The cytokines and chemokines released by NK cells help in triggering and adjustment of immune responses against pathogens and malignancies [53, 54].

Unlike T and B lymphocytes, NK cells do not express antigen-specific recognizing receptors (e.g., TCR by $\mathrm{T}$ cells). Abnormal cell recognition by NK cells mainly relies on a balance between inhibitory and activating signals. NK cells have a complex collection of receptors capable of signaling either inhibiting or activating messages. The receptor repository of NK cells contains mainly the non-specific primary receptors that make NK cells capable of exerting more general and not antigenand TCR-restricted recognition (unlike the $\mathrm{T}$ cells). The receptors can be considered as a kind of pattern recognition receptors, not antigen-specific receptors [55]. In other words, NK cells at the same time express both inhibitory and activating receptors, and their cytotoxic functions can be initiated when a balance between the signaling network of inhibitory receptors and activating immune receptors is interrupted [56]. Inhibitory receptors have a key role in the selectivity function of NK cells by developing NK cells tolerance toward healthy normal cells. When those germline-encoded inhibitory receptors bind to major histocompatibility complex (MHC)-I on a normal cell, a cascade of intracellular signaling mechanisms is triggered: $\mathrm{SH}-2$ containing protein tyrosine phosphatase (SHP)-1 and SHP-2 are recruited to immunoreceptor tyrosine-based inhibitory motifs (ITIMs) in their cytoplasmic parts. These events oppose the kinases activated by activating receptors; thus, at the end, NK cells remain inactive [57]. Nevertheless, when abnormal conditions such as infectious disease or cancer occur, NK cells can be activated due to a lack of MHC-I on abnormal cells and receiving more activating signals [58].

The inhibitory receptors interacting with MHC molecules contain a large repertoire of receptors. The repertoire includes Ig-like receptor (KIR) on human NK cells while Ly49, a family of polymorphic type II proteins with C-type lectin domains, on murine NK cells $[47,59]$ and the heterodimeric C-type Lectin receptor (CD94/ NKG2A) which is similar in both human and mouse species [58].

Members of the KIR family normally recognize a subset of classic MHC-I molecules, including human leukocyte antigen (HLA-A, -B, and -C) [44]. In a similar manner, Ly49 recognizes a subset of $\mathrm{H}-2$ molecules [60]. 
However, CD94/NKG2A can link to non-classical MHCI molecules such as Qa-1b in mice and HLA-E in humans [61]. On the other hand, the activating receptors consist the natural cytotoxicity receptors (NCRs) NKp46, NKp30, NKp44, and the C-type lectin-like activating immunoreceptor NKG2D and 2B4 (CD244), Fcy RIIIA (CD16), and some others [62, 63].

Based on mentioned points above, NK cells recognize target cells through one of these models: "missing-self recognition," "stress induced-self recognition," and "nonself-recognition." Since MHC molecules expression on host cells downregulated or cell transformation occurred, NK cells activated in a process called "missing-self recognition" [64]. Under conditions that NK activating receptors distinguish upregulated self-proteins in transformed or infected cells, "Stress induced-self recognition" is a way of NK cells activation [64]. And finally, "Non-self-recognition" refers to the status that foreign pathogen-encoded molecules are identified by some NK activating receptors [65].

\section{CAR-NK cell immunotherapy}

It is more than a decade that NK cells have been reported as efficient effector cells in adoptive immunotherapy [66, 67]. Unlike $\mathrm{T}$ cell-mediated immunotherapy, anti-tumor responses of these cells are usually effectual due to distinct characteristics of NK cells including antigen-independent recognizing and no induction of immune-mediated dysfunctions such as $\operatorname{GvHD}[68,69]$.

In recent years, genetic manipulation of NK cells has been considered to improve cytotoxicity, tumor-targeting capability, and persistence in the tumor microenvironment (TME) [70]. One of the examples of these modifications is CAR transduction in NK cells [71]. The introduction of CAR-NK cells as a novel method of cellular immunotherapy has provided us new insights and opportunities to fight against malignancies and infectious diseases [72-74].

Similar to CAR-T cells, CAR-engineered NK cells have three parts; an extracellular region comprised of a single-chain variable fragment ( $\mathrm{scFv}$ ) to target a tumorspecific antigen, transmembrane, and intracellular domains [45]. First-generation CAR-NK cells only have a $\mathrm{CD} 3 \zeta$ chain as the signaling domain $[75,76]$. More investigations have shown that adding one or two costimulatory domains improves the potency and cytotoxicity of CAR-NK cells. Later in second- and third-generation, besides the primary $\mathrm{CD} 3 \zeta$ chain, NK cells were also equipped with additional specific signaling endodomains such as CD28, 2B4, 4-1BB, OX-40 DAP10, and DAP-12 [77-80] (Fig. 1). Compared to CAR-T cells, there are many advantages in applying CAR-transduced NK cells in targeted immunotherapy. First, because of no requirement of NK cells to HLA matching, they are tolerated well and do not lead to GVHD [81, 82]. Second, CAR-NK cells do not cause severe toxic effects; activated NK cells produce useful and safe cytokines such as IFN- $\gamma$ and GM-CSF while CAR-T cells principally release pro-inflammatory cytokines, such as TNF- $\alpha$, IL-1, and IL- 6 which then resulted in CRS [83-85]. Third, there are various sources of NK cells such as $\mathrm{PB}$, umbilical cord blood, human embryonic stem cells (hESCs), induced pluripotent stem cells (iPSCs), and even immortal cell lines [64, 86]. Finally, because of the short life of NK cells, on-target/off-tumor effects occur rarely [87]. Hence, these advantages have led to optimism and enthusiasm for using CAR-NK cells for immunotherapy instead of utilizing CAR-T cells.

\section{Sources for preparing CAR-expressing NK cells}

There are different sources that functional NK cells can be extracted and generated from [18]. One of these sources is PB-NK cells, which can be isolated from peripheral blood samples taken from donors or on a larger scale by apheresis. The advantages of these cells are their high expression of activating receptors, such as CD16, NKp44, and NKp46 and KIRs [88] permitting them to be activated readily, and additionally, PB-NK cells can be easily expanded in vivo without further stimulation processes [89].

However, working with blood NK-cells is challenging because of some difficulties in the collection, in vitro expansion, and transduction of these cells [24]. Autologous NK cells can lose their efficacy within the body. The reason behind this issue is that they undergo inactivation processes when they come across to self-MHC presented by cells. On the other hand, using allogenic NK cells have the risk of GvHD even after the CD3 lymphocytes have been depleted [90].

The second source of NK cells is derived from immortal NK cell clones. These cell lines have good cytotoxic potential. Some of these cell lines are NKG, NKL, KHYG-1, HANK-1, YT, NK-YS, YTS, SNK-6, IMC-1, and NK-92 cells [24]. They are more suitable sources for CAR-engineering techniques than PB-NK cells due to their homogeneous cell population, easy expansion procedures, and no need for donors [91]. NK-92 cell line was first isolated from a male patient with nonHodgkin's lymphoma [92] and was the most frequently used cell line for CAR-NK cell preparation in studies and even has been utilized in clinical trials (NCT00900809 and NCT00990717).

However, the strengths and weaknesses usually come together, and the NK cell lines suffer from some disadvantages such as the lack of CD16 expression in most cell lines and non-permanent expression or lack of important activating receptors like natural cytotoxicity receptors (NCRs) [92, 93]. Furthermore, they might cause 


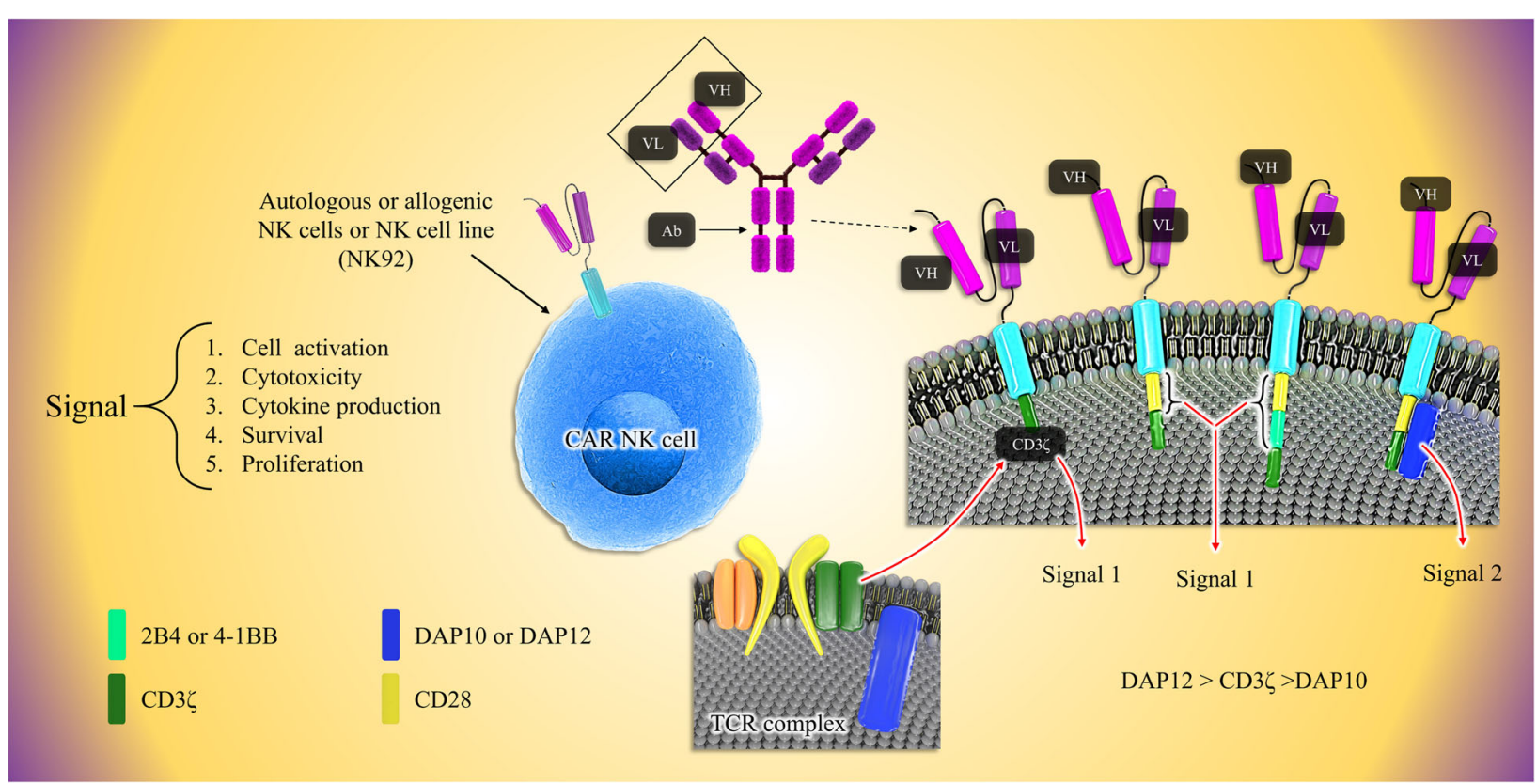

Fig. 1 The fundamentals of CAR engineering of three generations of CAR-NK cells. CAR molecules on NK cells consist of three main parts: an antigen detection domain (e.g., ScFv), a transmembrane domain, and the signaling domain. First-generation CARs consist of CD3Z as the signaling domain. Second-generation CARs have the CD-28 or a combination of CD-28 and a second additional signaling molecule: 4-1BB. As an example of 3rd generation, a CAR comprising an activating receptor; NKG2D can be constructed containing the signaling molecules: CD3Z and DAP10/12. It was found that $\mathrm{CD} 3 \zeta$ has better signaling properties than DAP10 and also it seems that DAP12 may activate NK cells better than both CD3ろ and DAP10. NK cells antigen binding or receiving activation signal by a bunch of activator receptors such as NKG2D leads to signal transduction, NK cell activation, the release of cytolytic enzymes, cytokine production, and also NK cells expansion and maintenance

multiple cytogenetic abnormalities and suffer from low persistence in vivo [94].

Although in experimental studies NK-92 cells succeed in restraining tumor burden, due to the short lifespan, they lack sufficient long-term therapeutic efficacy in xenograft mouse models $[33,95]$. Furthermore, there are some concerns about the tumorigenesis potential of NK-92 cells. To deal with this issue, NK-92 cells are irradiated before injection to patients [96, 97]. Another concern refers to the triggering stroke due to injection procedure and NK-92 cell aggregation in mice $[24,73,98]$.

NK-92MI and NK-92CI cells were derived from NK-92 cells and have biological characteristics similar to their progenitors, but are not dependent on IL-2 stimulation [99]. In recent years, NK cells originated from hESCs and iPSCs have been gaining more interest as the sources for producing engineered NK cells. iPSC/hESC-derived NK cells express general NK cell markers such as KIRs, CD16, NKp44, NKp46, NKG2D, and TRAIL, and also, they have shown cytotoxicity against several types of hematological and solid tumors in vitro [100, 101]. Therefore, iPSC/ hESC-derived NK cells may be good candidates for CAR engineering to fight against different cancers. In an ovarian cancer xenograft model, CAR-expressing iPSC-NK cells exhibited good antitumor activity, significantly inhibited growth and prolonged survival compared to PB-NK cells, unmodified iPSC-NK cells, or iPSC-NK cells expressing conventional T-CAR (constructed with CD28-4-1BB $\zeta$, not the NK cellderived activating domains) [102]. Interestingly, the in vivo persistent NK cells were significantly increased in the circulation, spleen, and peritoneal fluid in a separate group of tumor-bearing mice post-injection compared to mice injected with PB-NK cells and iPSC-NK cells after 10 days [102]. Also, NK-CARiPSC cells targeting CD19 showed remarkable efficiency in controlling CD19+ leukemia progression in humanized mouse models, while less occurrence of side-effects such as CRS [103].

Furthermore, stem cell progenitors have been introduced as a unique source to be differentiated into NK cells. Additionally, NK cells can be directly isolated from the umbilical cord blood (CB). The low immunogenicity of cord blood cells significantly reduces the risk of relapse and GvHD [104]. Recently, CB-NK cells transduced with CAR-CD19, IL-15, and inducible caspase-9 (iC9) suicide gene have shown enhanced persistence and antitumor activity in a Raji lymphoma mouse model [55]. However, further research is needed to determine whether these cells can be properly activated and can elicit efficient cytotoxicity against tumor cells. 
In vitro culturing conditions and expansion of NK cells Naturally, NK cells have a short lifespan. Primary NK cells or CAR-NK cells can be induced to proliferate and last longer within the body. Some endogenous or exogenous stimulating mediators (e.g., cytokines) can be used to provide stimulus. Using growth/proliferation promoters in vitro requires time-consuming and sometimes high-cost techniques and procedures $[105,106]$. Also, isolation and purification of NK cells from sources such as peripheral blood mononuclear cells (PBMCs) and umbilical cord blood is a quite complex process. It needs sophisticated equipment for cell sorting: flowcytometer. To use a flow-cytometer, further procedures such as sample preparation and multiple antibodies to detect NK cell markers (i.e., CD56, CD16) should be performed [107]. It seems that we need to develop costeffective methods for in vitro preparation of NK cells and keeping them persistent within the body. Natural/ primary NK cells need nutrition-rich mediums such as the stem cell growth medium (SCGM) and as well as the feeder cells such as K562 to accompany, feed, and stimulate them in vitro cell culture. Co-culturing NK cells with irradiated stem cells as feeder cells can also lead to activation of NK cells. Stem cells themselves can be plated in suitable conditions (i.e., stimulatory cytokines and feeder layer) to be differentiated into NK cells. Stimulatory molecules such as the phytohemagglutinin (PHA) and anti-CD3 monoclonal antibody (OKT3) can be used to trigger the proliferation of NK cells [108, 109]. PHA often is used for the activation of human PBMCs. Also, PHA is a good activator of PBMC-derived NK cells in vitro. There are three cytokines with clear boosting activity on NK cells' function and expansion in vitro: IL-2, IL-3, IL-15, IL-21, and FLT-3L. Each of these cytokines alone or their combination(s) can activate NK cells to proliferate and attack the cancer cells. Inducing endogenous IL-2, IL-15, and IL-21 or administering them exogenously in vivo experiments can lead to NK cell expansion and persistence. IL-2, zoledronate, and Group A streptococcus are potentiating and activating factors for the immune system and immune cells which can also be used to stimulate CB-derived NK cell proliferation/expansion. Unlike the difficulties with PBMC/CB-derived CAR NK cells, we face far fewer problems with CAR-NK cells prepared from cell lines such as NK92 and NK101. The cell lines have good features such as good proliferation rate, easy in vitro expansion and preparation procedures and more durability within circulation [110].

\section{Transduction methods for CAR-NK cell engineering}

For more than a decade, scientists have followed different methods to genetically modify NK cells to utilize them as immunotherapeutic agents in cancer. There are various modification strategies to improve effector functions, persistence, safety, and efficacy of NK cells.

Increased persistence was achieved by genetically manipulating the cytokine-expressing NK cells which as a result, enhanced their stability within TME via selfexpression of IL2 and IL-15. Therapeutic efficacy was achieved by the expression of CAR on NK cells to target specific tumor antigens. Better safety can also be obtained by the incorporation of suicide genes into NK cells [111]. In summary, incorporation of a foreign gene into an immune cell requires specific vector systems including (a) viral vectors or (b) non-viral vectors. Despite the difficulties of viral vector transduction in NK cells, the efficacy of these vectors is relatively higher than non-viral systems. It is also interesting to mention that the transduction efficacy in NK cells usually is higher than that in $\mathrm{T}$ cells. The most commonly used vectors for introducing CAR genes are viral vectors derived from different virus families such as the retrovirus family; $\alpha$-, $\beta-, \gamma_{-}^{-}, \delta$-, and $\varepsilon$-retroviruses [112], spumaviruses, and lentiviruses [113].

One of the advantages of lentiviral vectors over retroviral vectors is their capability to infect both dividing and non-dividing cells. Retroviral vectors can only infect dividing cells [114]. Another benefit is the capability of the lentiviral vector to carry larger transgenes in comparison to retroviral vectors [115]. One issue during the transduction of an NK cell is that the gene-encoding vector can be arbitrarily and stably integrated into the cell's genetic material. This issue can lead to mutagenesis which was reported in several experiments. In these studies, $\gamma$-retroviral vectors were used to find a treatment solution for different diseases such as X-linked severe combined immunodeficiency (X-SCID) and Wiskott-Aldrich syndrome [116-118].

The efficacy of retroviral transduction is very high in expanded primary NK cells with a median of 69\% (4393\%) [79], but this gene delivery system has been known for some pitfalls such as insertional mutagenesis, and constant and uncontrolled opposing effects because of improper transgene expression. On the other hand, although lentiviral vectors have a lower risk of inducing insertional mutations, their transduction efficacy in PB NK cells is low; between $8 \%$ and $16 \%$. However, the transduction efficacy of these vectors to deliver CAR genes into cord blood-derived NK cells was reported $73 \%$ [119]. Due to the drawbacks and safety concerns of viral transduction, a non-viral alternative such as the transposon/transposase system $[120,121]$ and mRNA transfection $[110,112]$ have been progressed and tested from the last two decades till now $[75,119]$. The nonviral-based gene delivery methods comprise all synthetic gene carriers capable of inducing relatively stable gene expression in target immune cells such as NK cells. The 
success of non-viral gene delivery is tightly associated with proper selection of two factors: (a) physical delivery methods such as the electroporation and sonoporation, microinjection, and magnetofection and (b) the gene carriers and enhancing buffers such as the biphasic polymers or liposomes or other carriers. These carriers can merge with cell membranes and insert the gene codes into cells. They induce temporary expression of target genes, last a few days, and disappear in dividing cells after a short time [122, 123]. Also, these vectors are inexpensive and have low immunogenicity, but they cannot integrate transgenes into the genome, and they just induce a temporary expression of desired genes [17].

There are also much safer non-viral methods to deliver genetic material into the target cells such as electroporation, sonoporation, microinjection, magnetofection, and patented nucleofection technique. Electroporation-based methods are safer compared to viral methods due to the transient nature of delivered foreign genetic materials (e.g., mRNA), applicable in both dividing and nondividing cells, and no need for direct manipulation of the cell's genome [124-126]. This method is based on creating a temporary pore on the cell membrane that provides a transient insertion channel into the cell. However, one of the problems of this method is the possibility of cell damage due to permanent electroporation [127]. As reported recently, mRNA encoding CARs were successfully electroporated into peripheral blood-derived NK cells with an efficiency of up to $81 \%$ [128]. The NK cells electroporated with these mRNAs exhibited a distinct increase in their cytotoxicity against $\mathrm{B}$ cell malignancies in vitro and in preclinical animal models, which later led to a trial exploring their use in humans $[128,129]$. Another noticeable point is that whereas viral-based methods usually need to be performed on dividing cells at their exponential growth phase, the electroporation-based methods do not require the cells to be on their division phase and are successful in both dividing and non-dividing cells. Early studies utilizing the electroporation method for delivery of genetic material into NK cells have shown over $50 \%$ of efficacy. This method has been also used for engineering CARNK cell targeting CD20 antigen on cancerous cells in B cell non-Hodgkin lymphoma [130] and Burkitt lymphoma [78]. Also, NK cells nucleofected with anti-ROR1 CAR mRNA were used for the treatment of metastatic solid tumors [131, 132].

In the last two decades, an interesting biologic phenomenon was discovered referring to the transfer of intact membrane patches during immune-cell contacts through an immunological synapse (IS) which was later named trogocytosis. It was also found that this mechanism of exchanging cellular components (e.g., the surface receptors) [133] can also be utilized for delivering directly the entire anti-CD19 CARs (not just mRNAs) to NK cells. In a recent study, anti-CD19 CAR-expressing K562 cells were used as donor cells in a co-culture with peripheral blood-derived CD56 + CD3-NK cells. After co-culture, the presence of CAR molecules on NK-cells proved the successful transfer of anti-CD19 CAR from K562 cells to NK-cells through trogocytosis. However, this method is very new and immature and further research is required to prove its clinical relevance [134].

PiggyBac transposon system is another effective nonviral method for genetic element delivery. The system is based on an enzyme (i.e., transposase) that can targetspecific sequences on DNA. The enzyme called transposase recognizes the transposon-specific inverted terminal repeat sequences (ITRs) located on both ends of a transposon vector and then simply cut the sequence and paste it somewhere on the target DNA. Therefore, upon recognition, the transposase easily integrates genetic elements from the original sites into chromosomal sites. This creates stable/permanent genomic integration of genomic material [135]. This technique has been also used for CAR modification of $\mathrm{T}$ cells $[55,136]$. But in terms of NK cells, only two studies are reporting the introduction of CARs to NK cells with the help of the piggyBac transposon system. In one study, Wang et al. engineered NK cells with NKG2D-CAR-presenting vectors with the help of the piggyBac transposon system. They also incorporated DAP10 and $\mathrm{CD} 3 \zeta$ as the cosignaling domains within the CAR construct to be used for the transposition process. Besides, they blocked NKcell-suppressing CD73 markers on cancer cells using the anti-CD73 antibodies. The results of this study exhibited that CD73 blockade can neutralize the purinergicmediated immunosuppression and enhance antitumor cytotoxicity of NKG2D-CAR-NK cells in both in vitro and in vivo conditions against solid tumor [137]. In another study, NK-cells derived from iPSCs were modified genetically using the piggyBac system to introduce them a CAR construct containing the transmembrane domain of NKG2D, the 2B4 co-stimulatory domain, and the $\mathrm{CD} 3 \zeta$ signaling domain. The resulted NK-CAR-iPSC-NK cells could successfully mediate strong anti-tumor activity and repressed tumor growth and prolonged survival compared to PB-NK cells, iPSC-NK cells, or T-CARiPSC-NK cells (Fig. 2) [102].

\section{Pre-clinical and clinical studies \\ Pre-clinical studies in hematological malignancies}

CAR-based immunotherapy in hematological malignancies such as leukemia and lymphoma has been probably the most efficient therapeutic method to date because of its impressive power to elicit an anti-tumor response. CAR-NK cells and CAR-T cells both have been 


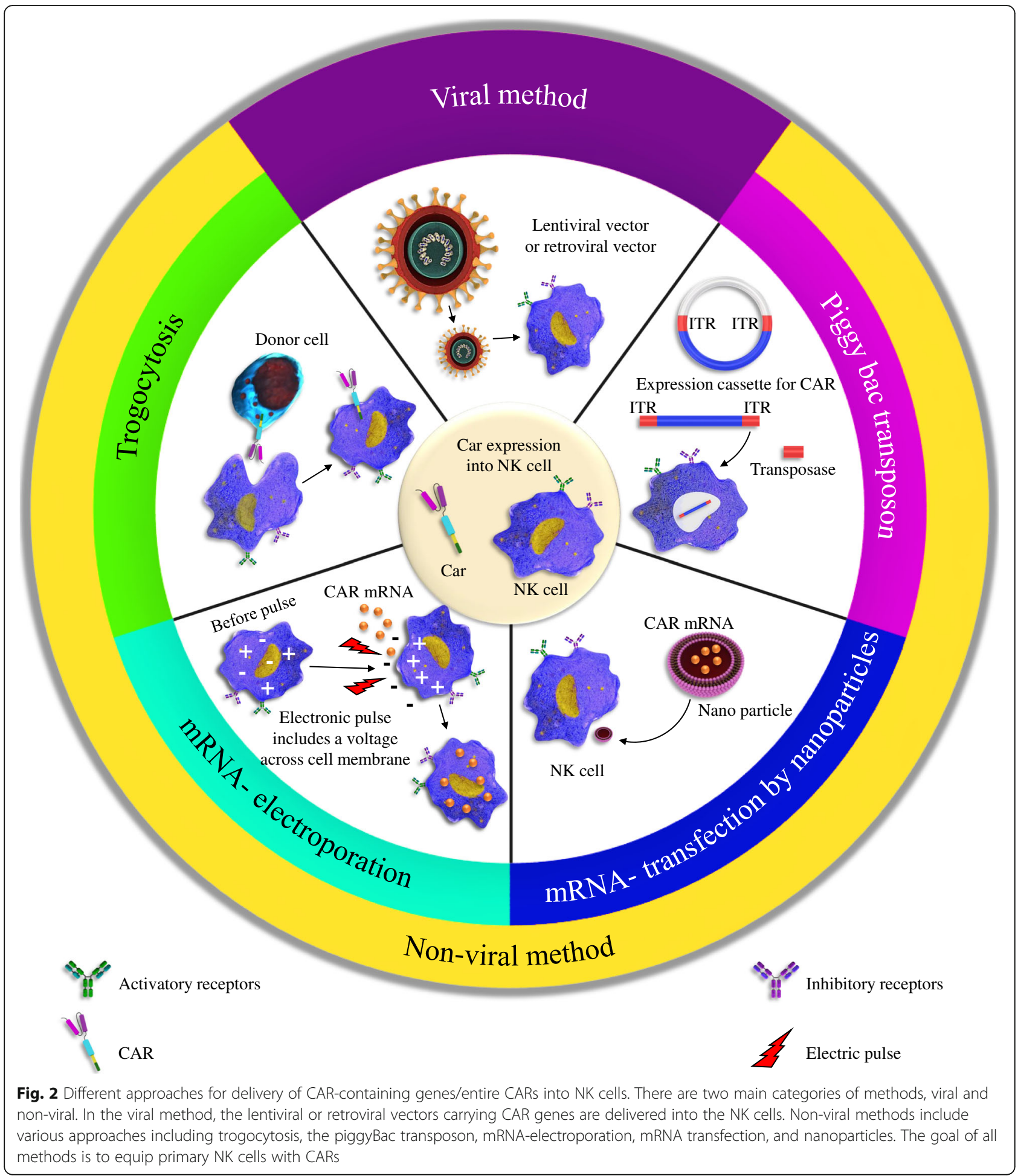

successful to open new clinically relevant opportunities for the treatment of these malignancies.

Many ex vivo studies have investigated the efficacy of CAR-NK cells, and some of them are still in progress to improve the efficacy of CAR constructs. Many of the earlier preclinical studies of CAR-NK cells focused on targeting $\mathrm{B}$ cell malignancies through utilizing the antiCD19 and CD20-CARs [128, 129, 138]. In one study, CAR-NK cells were successfully produced by transduction of a CD19-specific CAR in hematopoietic stem/progenitor 
cells (HSPCs) and then differentiation into CAR-NK cells. The CAR-NK cells then could target the CD19-positive cells in B-linage malignancies [139] (Please see Fig. 3).

According to some evidence, acute and chronic B cell leukemias tend to develop resistance against normal/unmodified NK cells, especially after repeated and inappropriate treatment. To overcome the resistance, first-generation CD19-specific CAR NK cells were designed to target CD19-positive leukemic cell lines and primary leukemia cells [76]. It was also reported that CD19-specific CAR-expressing NK-92 cells cause efficient lysis of CD19-positive B-precursor leukemia cell lines and lymphoblasts in leukemia patients [76]. In another study, NK-92 cells were equipped with firstgeneration CAR targeting CD20 antigen which also contains $\mathrm{CD} 3 \zeta$ chain as intracellular signaling moiety. Similar to results observed for CD19-specific CAR-NK, this CD20-specific CAR NK-92 showed noticeably enhanced cytotoxicity against CD20-positive malignant cells including the cancer cells resistant to primary NK cells in primary lymphoma and leukemia cells while remained non-toxic to CD20-negative cells with expression of CD20 [140] (109).

In vivo studies using CD19-CAR-NK92 cells have shown the efficient distribution of the cells throughout the circulation and also good killing activity in leukemia murine models $[75,138]$. In other recent studies, the mechanistic rationale of the NK-based therapy in bNHL (B cell non-Hodgkin's lymphoma) was investigated. Also, the therapeutic potency and cell-cell interaction kinetics of CD19-CAR-NK cells as the "off the shelf" therapy were studied in vitro and in vivo models: bNHL cell lines, primary patient-derived cells, and in vivo xenograft model. Besides, systems biology transcriptomic analyses of flow-sorted lymphoma cells co-cultured with CD19CAR-NK92 cells revealed activation of important pathways involved in lymphoma cells: IFN $\gamma$ signaling, apoptosis mechanisms, ligand binding, and immunoregulatory and chemokine signaling pathways. Therefore, CD19-CAR-NK92 could trigger significant antilymphoma activity across a host of sensitive and resistant lymphoma cells that involved distinct NK cell-lymphoma cell interaction-mediated activation of cell death mechanisms [141] (Fig. 3).

Adoptive immunotherapy by (CAR)-engineered NK cells has been also examined for anti-cancer activity against Pre-B cell acute lymphoblastic leukemia (Pre-BALL). Exposure of Pre-B-ALL cell lines and primary blasts to FLT3-specific CAR NK-92 cells resulted in notable selective cytotoxicity of NK cells against them. Besides, FLT3-specific CAR NK-92 was effective in an SEM Pre-B-ALL xenograft model in NOD-SCID IL2R $\gamma^{\text {null }}$ mice to exert high antileukemic activity and inhibit cancer progression [142].

Furthermore, the anti-cancer efficiency of CAR-NK has also been studied in non-Hodgkin's lymphomas (NHLs) with poor prognosis such as aggressive $\mathrm{T}$ cell malignancies. It was found that CD5 or CD3 specific

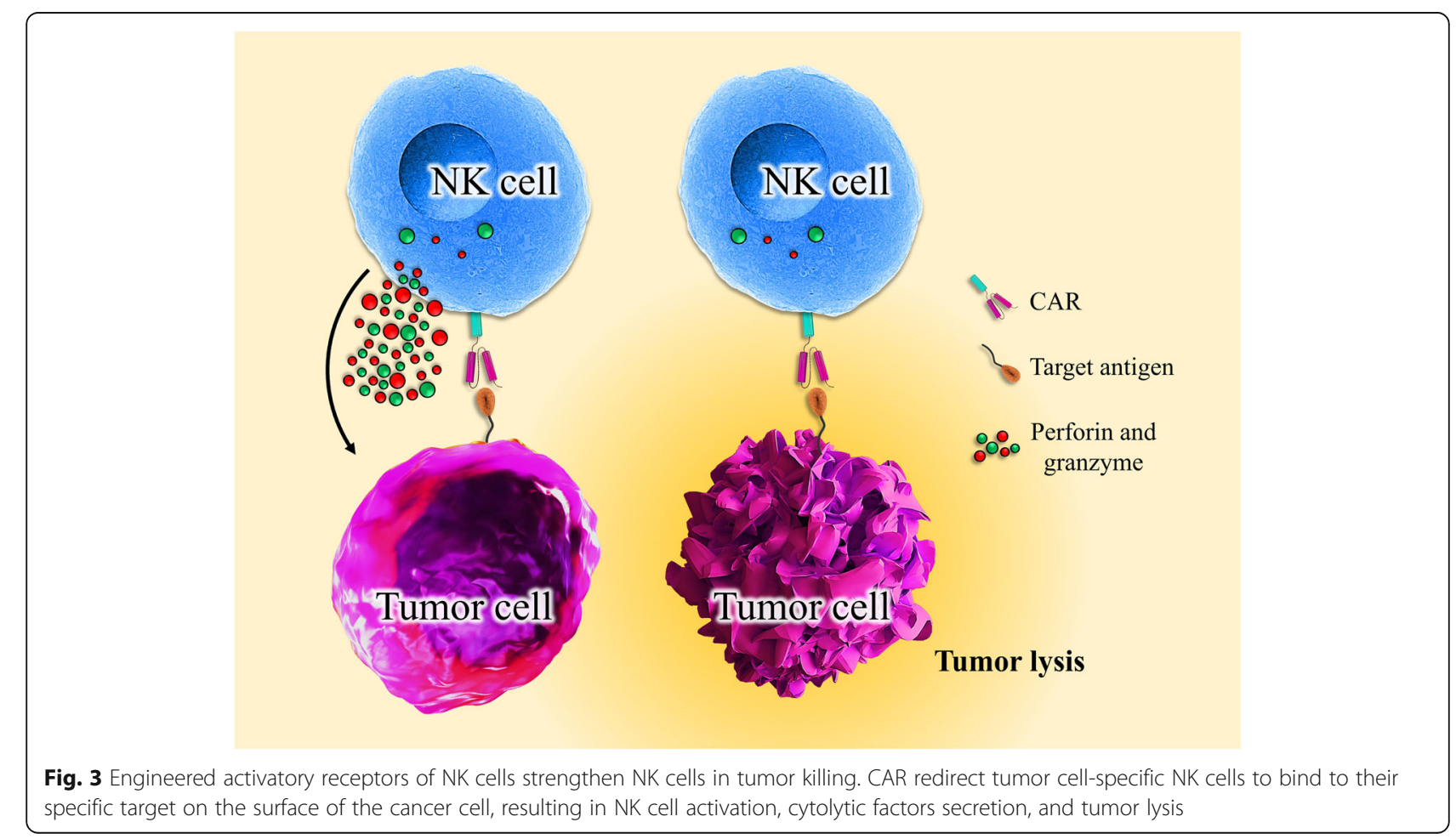


CAR-NK92 cells can maintain their stable expansion $[98,143]$ and exert efficient anti-tumor activity toward T cell leukemia, lymphoma cell lines, and primary malignant cells $[98,143]$.

MM as another type of malignant hematological cancer is characterized by abnormal proliferation of plasma cells in the bone borrow. These abnormal plasma cells then produce and secrete abnormal antibodies which can be detected in the serum or urine [144]. Application of CS1-specific CAR NK cells in MM was studied and tested for their potential anti-tumor activity in vitro and in vivo in MM-xenograft mouse models. The study used allogenic NK cells as a source for the development of CAR-NK cells. Using this type of cell may help to inhibit GvHD and increase NK cytotoxicity due to having nonmatching killer immunoglobulin-like receptors (KIRs) [81, 145]. CS1-specific CAR-NK92 cells were generated by introducing an anti-CS1 CAR construct containing CD28-CD3 $\zeta$ as a costimulatory domain into NK cells. It has been shown that the production of IFN- $\gamma$ was enhanced in vitro and tumor-killing activity in SCID gamma mice was induced [145]. CD138 is another antigen involved in MM development and proliferation and thus is a promising target for making CAR constructs. In a study, CD138-specific CAR NK-92MI displayed enhanced killing against CD138-positive human MM cell lines such as RPMI8226, U266, and NCI-H929 at various effector-to-target ratios [146]. Moreover, CAR-NK targeting CD138 has been successfully utilized in vivo experiments: xenograft NOD-SCID murine models [146].

\section{Preclinical studies on solid tumors}

CAR NK cell-based immunotherapies are also a promising therapeutic option for solid tumors. Glioblastoma (GB) is one of the most aggressive primary malignancies that can affect the central nervous system (CNS) [147]. Several GB-associated antigens have been incorporated in generating the CAR constructs. These most investigated GB-associated antigens include EGFR, EGFRvIII, and ERBB2 [130, 148, 149]. The therapeutic capacity of CAR-engineered NK cells for the treatment of GB has so far been studied by effector cells targeting EGFR, EGFRvIII, and ERBB2.

It has been shown that NK cell line YTS transduced with EGFRvIII-specific CAR construct can significantly display higher anti-cancer activity than the nontransduced cells which have no CAR. In this study, a CAR structure was designed and produced, consisting two parts, an antibody named MR1-1 with a scFv fragment capable of targeting EGFRvIII, and an intracellular part called DNAX-activating protein-12 (DAP12) to transfer the received signals into the cell [150]. DAP12 comprises an immunoreceptor tyrosine-based activation motif (ITAM) that transmits the activation signals for the NK cells [151]. Also, a study was shown that coexpression of the chemokine receptor CXCR4 in the EGFRvIII-specific CAR-NK cells improves the anticancer activity by enhancing tumor detection and homing properties of CAR-NK cells. These cells could trigger better inhibition of tumor growth and extended survival in EGFRvIII-positive GB xenografts in mice [150].

In another study, KHYG-1 NK cells with EGFRvIIIspecific CAR showed good cytolytic activity against cancer cells [152]. In another study, a second-generation CAR containing EGFRvIII-specific antibody MR1-1 as cancer-targeting domain and $\mathrm{CD} 28$ and $\mathrm{CD} 3 \zeta$ as signaling domains was used for transduction into the NK cell [148]. With the help of CARs, these engineered NK cells were redirected toward EGFRvIII-positive GB cells, resulted in quick and effective tumor cell killing. Moreover, EGFRvIII targeting NK-92 cells were frequently injected with the help of stereotactic method into orthotopic EGFRvIII-bearing GB xenografts in immunodeficient NSG mice which resulted in improved survival rate [148].

The receptor tyrosine kinase ErbB2 belongs to the same receptor family that EGFRvIII and EGFR are present, i.e., EGFR-related family of receptor tyrosine kinases. ErbB2 has also been incorporated in CARengineered NK-92 cells to be evaluated in cancer experiments [153]. It was found that ErbB2 is overexpressed in some types of human tumors with an epithelial origin and it is thought that it has a role in cancer development and progression $[4,154]$. Several CAR-engineering approaches capable of targeting the ErbB2-positive cancers are now in development process. The suitability of CARbased treatments for targeted cancer therapy was confirmed in both preclinical and clinical studies [155-157]. In this line, the genetically modified NK-92-scFv (FRP5)zeta cells showed a great promise in killing the several types of ErbB2-expressing tumor cells and introduced as a new therapeutic solution for the treatment of ErbB2expressing tumors [158].

In some preclinical studies, NK-92 cells were transduced with second-generation CARs containing a composite $\mathrm{CD} 28-\mathrm{CD} 3 \zeta$ signaling domain to target ErbB2positive cancer cells. These new CARs showed the strong and selective cytotoxicity against ErbB2-bearing target cells originated from different types of solid tumors such as the GB-related cell lines and primary GB stem cell cultures $[153,159]$. Repeated stereotactic injection of these CAR-NK cells into the tumor location in orthotopic GB xenograft models efficiently repressed tumor progression and led to a marked prolongation of survival time [153]. In a study, the majority of mice whose had normal immune system and carrying syngeneic intracranial GL261/ErbB2 glioblastomas showed powerful endogenous antitumor immunity after 
intratumoral injection of NK-92/5.28. z cells. Unchanged NK-92 cells failed to inhibit tumor progression [153, 160]. Advanced renal cell carcinoma (RCC) is another solid tumor that has been evaluated with antigenspecific CAR-NK cells [161]. In this regard, a carbonic anhydrase IX (CAIX)-specific third-generation CARNK92 cells were utilized. In vitro consideration indicated that CAR-NK92 had a remarkable cytotoxic effect on target cells. Furthermore, a combination of bortezomib with CAR-NK92 cells showed greater suppressive efficacy against CAIX-positive tumor xenografts in comparison to the monotherapy with either CAR-NK92 cells or bortezomib [161].

Another group, Qing Zhang et al. constructed specific second-generation CAR-NK92 cells against an epithelial cell adhesion molecule- (EpCAM-) in colorectal cancer cells (CRC) [162]. In vitro results exhibited that EpCAM-specific CAR-NK-92 cells have a high potential cytotoxic effect against CRC cells. On the other hand, they reported a novel regimen, combination therapy with EpCAM-specific CARNK-92 cells and regorafenib, which increased anti-tumor efficacy to treat colorectal cancer in mouse models [162]. The synergy between the Robo1 BiCAR-NK immunotherapy and ${ }^{125}$ I has been examined in a murine model of orthotopic pancreatic tumor. The results illustrated that those groups treated with ${ }^{125}$ I seed +CAR-NK had higher tumor repression than ${ }^{125}$ I seed treatment alone. Consequently, this study indicated that ${ }^{125}$ I seed brachytherapy accompanied with Robo1-specific CAR-NK immunotherapy leads to better anti-cancer efficacy in a murine model of orthotopic pancreatic cancer [163]. A novel combination therapy consisting EGFR-CAR-NK-92 cells and a type of oncolytic virus was very effective against breast cancer brain metastases and could significantly increase survival time of tumor-bearing mice [164]. Reprogramming of NK cells has also been tested in proliferative prostate cells. CAR targeting PSCA which comprises DAP12 has been invented with NK cell line YTS [151]. Contacting of PSCA and anti-PSCA scFv (AM1) resulted in phosphorylation of DAP12-associated ZAP-70 kinase and enhanced IFN- $\gamma$ production [151]. Besides, $\mathrm{GD}_{2}$-specific CAR NK cells in primary donor-drive NK cells and NK92 cell line which carrying first- or second-generation CARs have been utilized in preclinical in vitro and in vivo models of neuroblastoma $[165,166]$ and Ewing sarcoma [167] which had effective antitumor activity. The introduction of CARs represents the most studied and developed approach that has recently reached preclinical evaluation (Table 1).

\section{Clinical study}

Although CAR $\mathrm{T}$ cell therapy has shown promising results in the treatment of acute lymphoblastic leukemia the method has not been so good at the treatment of acute myeloid leukemia. As an alternative approach, CD33-directed CAR-NK-92 cells were evaluated in phase 1 clinical trial in patients with refractory acute myeloid leukemia without major adverse effects, indicating that CAR-NK cells may be a safe alternative for CAR-T cells [183]. However, CAR-NK cells have some limitations such as short life-time, low capacity to infiltrate into the tumor sites, and weak cytotoxicity in vivo [184]. To improve the proliferation capacity and persistence of NK cells, an optimized CAR-NK cell construct named CD19-CD28-zeta-2A-iCasp9-IL15 comprised the coding sequence of IL-15 was transduced into cord blood natural killer (CB-NK) cells. The optimized CARNK cells showed great potency in destroying the cancer cells in patients with relapsed/refractory CD19+ B lymphoid malignancies (NCT03056339).

Furthermore, to evaluate the safety and feasibility of CAR-NK cell treatment in patients with metastatic solid tumors phase 1 of a clinical trial are now in progress. For this aim, CAR-NK cells targeting NKG2D ligands are being utilized and following infusion of CAR-NK cells interleukin-2 (IL-2) will be injected subcutaneously into some patients to support the survival of CAR-NK cells in vivo (NCT03415100).

Treatment with Robo1 BiCAR-NK could improve ${ }^{125} \mathrm{I}$ seed brachytherapy in vitro and in vivo in pancreatic cancer models [163]. It has been shown that this combination therapy resulted in higher tumor reduction significantly. For this purpose, Robo1 BiCAR-NK92mediated immunotherapy is now tested in phase I/II clinical trials in patients with relapsed and refractory pancreatic cancer (NCT03941457). Details have been shown in Table 2.

\section{Challenges of using CAR-NK cells and strategies for improving their functions Efficacy of transduction methods}

Despite the many advantages of using NK cells, some challenges limit these effector cells to generate CARmodified NK cells for clinical application [185]. To begin with, the efficacy of transduction methods is one of the challenges to be considered since lentiviral vectors (LVs) have just received some attention as a vehicle for CAR transduction with high potential and high efficacy in clinical uses [53, 186, 187]. However, these vectors have the risk of inducing mutagenesis, so is not desirable for human [188]. On the other hand, in non-viral methods such as mRNA electroporation, the transcript cannot integrate into the genome because of its short-expression time [128]. Moreover, larger quantities of mRNA would be required for clinical applications that multiple infusions would be necessary to make up for the transient expression of the CAR proteins. As stated by some 
Table 1 Preclinical trials of CAR-engineered NK cells

\begin{tabular}{|c|c|c|c|c|c|}
\hline \multicolumn{6}{|c|}{ Hematological malignancies } \\
\hline Target & Malignancy & $\begin{array}{l}\text { Signaling } \\
\text { domain }\end{array}$ & Source of NK cells & Genetic modification method & Reference \\
\hline CD19 & $\begin{array}{l}\text { B cell acute lymphoblastic } \\
\text { leukemia (B-ALL)/B cell } \\
\text { malignancies }\end{array}$ & $\mathrm{CD} 28+\mathrm{CD} 3 \zeta$ & $\begin{array}{l}\text { Primary human NK cells } \\
\text { from PBMCs }\end{array}$ & Lentiviral transduction & {$[168]$} \\
\hline CD19 & $\begin{array}{l}\text { B cell acute lymphoblastic } \\
\text { leukemia (B-ALL)/B cell } \\
\text { malignancies }\end{array}$ & $2 \mathrm{~B} 4+\mathrm{CD} 3 \zeta$ & $\begin{array}{l}\text { Primary human NK cells } \\
\text { from PBMCs }\end{array}$ & retroviral transduction & [165] \\
\hline CD19 & $\begin{array}{l}\text { B cell acute lymphoblastic } \\
\text { leukemia (B-ALL)/B cell } \\
\text { malignancies }\end{array}$ & $4-1 \mathrm{BB}+\mathrm{CD} 3 \zeta$ & $\begin{array}{l}\text { Primary human NK cells } \\
\text { from PBMCs }\end{array}$ & mRNA electroporation & [128] \\
\hline CD19 & $\begin{array}{l}\text { (B-ALL) and non-Hodgkin } \\
\text { lymphoma (NHL)/B cell } \\
\text { malignancies }\end{array}$ & $4-1 \mathrm{BB}+\mathrm{CD} 3 \zeta$ & $\begin{array}{l}\text { Primary human NK cells } \\
\text { from PBMCs }\end{array}$ & $\begin{array}{l}\text { mRNA electroporation; retroviral } \\
\text { transduction }\end{array}$ & [129] \\
\hline CD19 & $\begin{array}{l}\text { B-ALL cells/ B cell } \\
\text { malignancies }\end{array}$ & 4-1BB/CD3द & $\begin{array}{l}\text { Primary human NK cells } \\
\text { from PBMCs }\end{array}$ & Trogocytosis & [134] \\
\hline CD19 & B cell malignancies & $\mathrm{CD} 3 \zeta$ & UCB & Retroviral transduction & {$[55]$} \\
\hline CD19 & B cell malignancies & $\mathrm{CD} 3 \zeta$ & NK-92 cells & Retroviral transduction & {$[76]$} \\
\hline CD19 & CLL/ B cell malignancies & $\mathrm{CD} 3 \zeta$ & NK-92 cells & mRNA electroporation & {$[75]$} \\
\hline CD19 & B cell malignancies & $\begin{array}{l}\mathrm{CD} 3 \zeta \\
\mathrm{CD} 28+\mathrm{CD} 3 \zeta \\
4-1 \mathrm{BB}+\mathrm{CD} 3 \zeta\end{array}$ & NK-92 cells & Lentiviral transduction & [169] \\
\hline CD19 & $\begin{array}{l}\mathrm{CD} 20 \text { resistant non-Hodgkin } \\
\text { lymphoma (bNHL) }\end{array}$ & $\mathrm{CD} 28+\mathrm{CD} 3 \zeta$ & NK-92 cells & NR & [141] \\
\hline CD20 & $\begin{array}{l}\text { B cell malignancies non- } \\
\text { Hodgkin lymphoma (bNHL) }\end{array}$ & $4-1 B B+C D 3 \zeta$ & $\begin{array}{l}\text { Primary human NK cells } \\
\text { from PBMCs }\end{array}$ & mRNA electroporation & {$[170]$} \\
\hline CD20 & B cell malignancies & $\mathrm{CD} 3 \zeta$ & NK-92 cells & Retroviral transduction & [140] \\
\hline CD19 and CD20 & B cell malignancies & $\mathrm{CD} 3 \zeta$ & NK-92 cells & Lentiviral transduction & [171] \\
\hline CS1 & Multiple myeloma & $\mathrm{CD} 28+\mathrm{CD} 3 \zeta$ & NK-92 cells & Lentiviral transduction & [145] \\
\hline CD138 & Multiple myeloma & $\mathrm{CD} 3 \zeta$ & NK-92Ml cells & Lentiviral transduction & [146] \\
\hline FLT3 & B-ALL/B cell malignancies & $\mathrm{CD} 28+\mathrm{CD} 3 \zeta$ & NK-92 cells & Lentiviral transduction & [142] \\
\hline CD5 & T cell malignancies & $\begin{array}{l}\mathrm{CD} 28+4- \\
1 \mathrm{BB}+\mathrm{CD} 3 \zeta\end{array}$ & NK-92 cells & Lentiviral transduction & [73] \\
\hline CD5 & T cell malignancies & $\mathrm{CD} 28+\mathrm{CD} 3 \zeta$ & NK-92 cells & Lentiviral transduction & [172] \\
\hline CD3 & T cell malignancies & $\begin{array}{l}\mathrm{CD} 28+4- \\
1 \mathrm{BB}+\mathrm{CD} 3 \zeta\end{array}$ & NK-92 cells & Lentiviral transduction & [98] \\
\hline CD4 & T cell malignancies & $\begin{array}{l}\mathrm{CD} 28+4- \\
1 \mathrm{BB}+\mathrm{CD} 3 \zeta\end{array}$ & NK-92 cells & Lentiviral transduction & [143] \\
\hline EBNA3C & EBV-positive T cells & $4-1 \mathrm{BB}+\mathrm{CD} 3 \zeta$ & NK-92Ml cells & Retroviral transduction & [173] \\
\hline \multicolumn{6}{|l|}{ Solid tumors } \\
\hline GD2 & Ewing sarcoma & $\begin{array}{l}\mathrm{CD} 28+4- \\
1 \mathrm{BB}+\mathrm{CD} 3 \zeta\end{array}$ & $\begin{array}{l}\text { Primary human NK cells } \\
\text { from PBMCs }\end{array}$ & Retroviral transduction & [167] \\
\hline GD2 & Neuroblastoma & $\mathrm{CD} 3 \zeta$ & NK-92 cells & Retroviral transduction & [166] \\
\hline GD2 & Neuroblastoma & $2 \mathrm{~B} 4+\mathrm{CD} 3 \zeta$ & $\begin{array}{l}\text { Primary NK cells from } \\
\text { PBMC and NK-92 cells }\end{array}$ & Retroviral transduction & [165] \\
\hline EpCAM & Breast cancer & $\mathrm{CD} 28+\mathrm{CD} 3 \zeta$ & NK-92 and NKL cells & Lentiviral transduction & [174] \\
\hline EpCAM & Colorectal cancer & $4-1 B B+C D 3 \zeta$ & NK-92 cells & Lentiviral transduction & [162] \\
\hline $\begin{array}{l}\text { Carbonic Anhydrase } \\
\text { IX (CAIX) }\end{array}$ & $\begin{array}{l}\text { Renal cell carcinoma } \\
\text { (RCC) }\end{array}$ & $\begin{array}{l}\mathrm{CD} 28+4- \\
1 \mathrm{BB}+\mathrm{CD} 3 \zeta\end{array}$ & NK-92 cells & Lentiviral transduction & {$[175]$} \\
\hline PSCA & $\begin{array}{l}\text { Prostate cancer/PSCA } \\
\text { tumor cells }\end{array}$ & DAP12 & $\begin{array}{l}\text { Primary human NK cells } \\
\text { from PBMCs and YTS cells }\end{array}$ & Lentiviral transduction & [80] \\
\hline GPA7 & Melanoma & $\mathrm{CD} 3 \zeta$ & NK-92 cells & mRNA electroporation & [176] \\
\hline
\end{tabular}


Table 1 Preclinical trials of CAR-engineered NK cells (Continued)

\begin{tabular}{|c|c|c|c|c|c|}
\hline \multicolumn{6}{|c|}{ Hematological malignancies } \\
\hline Target & Malignancy & $\begin{array}{l}\text { Signaling } \\
\text { domain }\end{array}$ & Source of NK cells & Genetic modification method & Reference \\
\hline GPC3 & $\begin{array}{l}\text { Hepatocellular carcinoma } \\
\text { (HCC) }\end{array}$ & $\mathrm{CD} 28+\mathrm{CD} 3 \zeta$ & $\begin{array}{l}\text { NK-92 and Primary human } \\
\text { NK cells from PBMCs }\end{array}$ & Lentiviral transduction & [177] \\
\hline CEA & Colorectal cancer & $\mathrm{CD} 3 \zeta$ & NK-92Ml cells & Retroviral transduction & [178] \\
\hline EGFR, EGFRvIII & $\begin{array}{l}\text { Glioblastoma multiform } \\
\text { (GBM) }\end{array}$ & $\mathrm{CD} 28+\mathrm{CD} 3 \zeta$ & $\begin{array}{l}\text { NK-92 and NKL and Primary } \\
\text { human NK cells from PBMCs }\end{array}$ & Lentiviral transduction & {$[130,148]$} \\
\hline EGFRvIII & Glioblastoma & DAP12 & YTS cells & Lentiviral transduction & [78] \\
\hline NKG2D & $\begin{array}{l}\text { Osteosarcoma; prostate, } \\
\text { colon, HCC, and breast } \\
\text { cancer (NKG2D) }\end{array}$ & DAP10 + CD3ろ & Primary NK cells from PBMC & Retroviral transduction & [179] \\
\hline NKG2D & $\begin{array}{l}\mathrm{CD}^{2} 3^{+} \text {solid tumors /lung } \\
\text { cancer }\end{array}$ & $\mathrm{DAP} 10+\mathrm{CD} 3 \zeta$ & NK-92 cells & PiggyBac transposon & [137] \\
\hline NKG2D & Ovarian cancer & $2 \mathrm{~B} 4+\mathrm{CD} 3 \zeta$ & iPSC-derived human NK cells & PiggyBac transposon & [102] \\
\hline ErbB2/HER-2 & $\begin{array}{l}\text { Breast/ovarian cancer/ } \\
\text { squamous cell carcinoma }\end{array}$ & $\mathrm{CD} 3 \zeta$ & NK-92 cells & Retroviral transduction & [158] \\
\hline ErbB2/HER-2 & Ovarian and breast cancer & $\mathrm{CD} 28+\mathrm{CD} 3 \zeta$ & Primary NK cells from PBMC & Retroviral transduction & [180] \\
\hline ErbB2/HER-2 & $\begin{array}{l}\text { Breast cancer/renal cell } \\
\text { carcinoma (RCC) }\end{array}$ & $\begin{array}{l}\mathrm{CD} 28+4- \\
1 \mathrm{BB}+\mathrm{CD} 3 \zeta\end{array}$ & NK-92 cells & Lentiviral transduction & [159] \\
\hline ErbB2/HER-2 & Glioblastoma & $\mathrm{CD} 28+\mathrm{CD} 3 \zeta$ & NK-92 cells & Lentiviral transduction & [149] \\
\hline ErbB2/HER-2 & Breast cancer & $\mathrm{CD} 28+\mathrm{CD} 3 \zeta$ & NK-92 cells & mRNA electroporation & [181] \\
\hline EGFR & $\begin{array}{l}\text { Renal cell carcinoma } \\
(\mathrm{RCC}) / \text { solid tumor }\end{array}$ & $\begin{array}{l}\mathrm{CD} 28+4- \\
1 \mathrm{BB}+\mathrm{CD} 3 \zeta\end{array}$ & NK-92 cells & Lentiviral transduction & [182] \\
\hline EGFR & $\begin{array}{l}\text { Breast cancer brain } \\
\text { metastases }\end{array}$ & $\mathrm{CD} 28+\mathrm{CD} 3 \zeta$ & $\begin{array}{l}\text { Primary NK cells from PBMC } \\
\text { and NK-92 cells }\end{array}$ & Lentiviral transduction & [164] \\
\hline
\end{tabular}

EGFR epidermal growth factor receptor, HCC hepatocellular carcinoma, PBMC peripheral blood mononuclear cell, CEA carcinoembryonic antigen, RCC renal cell carcinoma, CAIX carbonic anhydrase IX, UCB umbilical cord blood

studies, it has been shown that transduction method efficiency percentages are variable in various sources of NK cells [119]. In this regard, one study reported that the efficiency of primary $\mathrm{CB}$ or $\mathrm{PB}$-derived NK cells that were transfected by mRNA was $<10 \%[119,189]$. Viral transduction methods are very weak at transducing CAR into freshly isolated PB NK cells. However, it seems that NK cells at their activation and expansion stage are more susceptible to viral transduction methods. Much better transduction rate was achieved when NK cells from PB (12-73\%) [119] or in one study CB were activated and expanded (median 69\%; range 43-93\%) [79] and 80\% (range 67-96\%) in another study [179].

Another concern about immunotherapy with NK cells goes back to using allogeneic NK cells, which has the possibility of infusion contamination with $\mathrm{T}$ or $\mathrm{B}$ cells in the expanded NK cell preparation, which can initiate undesirable immune responses in receiver's body such as the GVHD or post-transplant lymphoproliferative disease [81].

\section{Potential challenges of NK cell expansion}

Furthermore, one more potential challenge to use NK cell-based immunotherapy is keeping NK cell expansion in the host's body after infusion. Because these cells are short-lived, it is necessary to use a new strategy for maintaining their numbers and activity [106, 190]. Recently, the administration of exogenous cytokines has been opening new prospects to tackle this issue. Regular IL-2 injection is an example to maintain function and biology of NK cells as desire; however, it can also induce regulatory $\mathrm{T}$ cell proliferation which suppresses NK cell functions [190, 191]. Therefore, other cytokines that can selectively activate NK cells have been explored [192]. On the report of a study, patients who were treated with strong lymphodepletion chemotherapy before NK cell infusion by using high-dose cyclophosphamide and fludarabine took advantage of better anti-cancer activity of NK cells and successful expansion of infused NK cells. In patients receiving high-dose lymphodepletion chemotherapy, a high level of endogenous IL-15 was observed indicating an important role of IL-15 in NK-cells expansion [89]. It was known that IL-15 does not induce Treg expansion [193]. Although exogenous IL-15 can lead to toxicities such as grade 3 hypotension, thrombocytopenia, and elevations of Alanine Transaminase (ALT) and Aspartate Transaminase (AST) and neutropenia, but these side-effects are dose-dependent. 
Table 2 Robo1 BiCAR- NK92-mediated immunotherapy tested in phase I/II clinical trials in patients with relapsed and refractory pancreatic cancer

\begin{tabular}{|c|c|c|c|c|c|c|c|}
\hline $\begin{array}{l}\text { Clinical trial } \\
\text { identifier }\end{array}$ & $\begin{array}{l}\text { Target } \\
\text { antigen }\end{array}$ & Condition or disease & Origin of NK cell & Construct & Phase & Status & Location \\
\hline NCT03824964 & $\begin{array}{l}\text { CD19/ } \\
\text { CD22 }\end{array}$ & Refractory B cell lymphoma & Allogeneic NK cells & Not mentioned & $\begin{array}{l}\text { Early } \\
\text { phase I }\end{array}$ & $\begin{array}{l}\text { Not yet } \\
\text { recruiting }\end{array}$ & Not mentioned \\
\hline NCT03940833 & BCMA & Multiple myeloma & NK 92 cells & Not mentioned & $|/| \mid$ & Recruiting & $\begin{array}{l}\text { Suzhou, Jiangsu, } \\
\text { China }\end{array}$ \\
\hline NCT02892695 & CD19 & Lymphoma and leukemia & NK 92 cells & Not mentioned & $|/| \mid$ & Unknown & $\begin{array}{l}\text { Suzhou, Jiangsu, } \\
\text { China }\end{array}$ \\
\hline NCT03579927 & CD19 & Lymphoma and leukemia & $\begin{array}{l}\text { Cord Blood NK } \\
\text { Cells }\end{array}$ & $\begin{array}{l}\text { CAR.CD19-CD28-zeta- } \\
\text { 2A-iCasp9-IL15 }\end{array}$ & $|/| \mid$ & $\begin{array}{l}\text { Not yet } \\
\text { recruiting }\end{array}$ & Houston, TX, USA \\
\hline NCT03692663 & PSMA & $\begin{array}{l}\text { Castration-resistant Prostate } \\
\text { Cancer }\end{array}$ & Not specified & Not mentioned & $\begin{array}{l}\text { Early } \\
\text { phase I }\end{array}$ & $\begin{array}{l}\text { Not yet } \\
\text { recruiting }\end{array}$ & Not mentioned \\
\hline NCT03692637 & Mesothelin & Epithelial ovarian cancer & Not specified & Not mentioned & $\begin{array}{l}\text { Early } \\
\text { phase I }\end{array}$ & $\begin{array}{l}\text { Not yet } \\
\text { recruiting }\end{array}$ & Not mentioned \\
\hline NCT03941457 & $\mathrm{ROBO} 1$ & Pancreatic cancer & Not specified & BiCAR-NK cells & $|/| \mid$ & Recruiting & Shanghai, China \\
\hline NCT03940820 & $\mathrm{ROBO} 1$ & Solid tumor & Not specified & Not mentioned & $|/| \mid$ & Recruiting & $\begin{array}{l}\text { Suzhou, Jiangsu, } \\
\text { China }\end{array}$ \\
\hline NCT03415100 & $\begin{array}{l}\mathrm{NKG} 2 \mathrm{D} \\
\text { ligands }\end{array}$ & Solid tumors & $\begin{array}{l}\text { Autologous or } \\
\text { allogeneic } \\
\text { NK cells }\end{array}$ & Not mentioned & 1 & Recruiting & $\begin{array}{l}\text { Guangzhou, } \\
\text { Guangdong, China }\end{array}$ \\
\hline NCT03056339 & CD19 & $\begin{array}{l}\text { Lymphoma and leukemia } \\
\text { (relapsed/refractory B cell } \\
\text { malignancy) }\end{array}$ & $\begin{array}{l}\text { Umbilical cord } \\
\text { blood I }\end{array}$ & $\begin{array}{l}\text { CAR.CD19-CD28-zeta- } \\
\text { 2A-iCasp9-IL15 }\end{array}$ & $|/| \mid$ & Recruiting & Houston, TX, USA \\
\hline NCT02944162 & CD33 & $\begin{array}{l}\text { Acute myeloid leukemia } \\
\text { (AML) }\end{array}$ & NK 92 cells & $\begin{array}{l}\text { CAR.CD28, CD137 and } \\
\text { CD3 zeta }\end{array}$ & $|/| \mid$ & Unknown & $\begin{array}{l}\text { Suzhou, Jiangsu, } \\
\text { China }\end{array}$ \\
\hline NCT03931720 & $\mathrm{ROBO} 1$ & Malignant tumor & Not specified & BiCAR-NKTT cells & $|/| \mid$ & Recruiting & $\begin{array}{l}\text { Suzhou, Jiangsu, } \\
\text { China }\end{array}$ \\
\hline NCT03692767 & CD22 & Refractory B cell lymphoma & Allogeneic NK cells & Not mentioned & $\begin{array}{l}\text { Early } \\
\text { phase I }\end{array}$ & $\begin{array}{l}\text { Not yet } \\
\text { recruiting }\end{array}$ & Not mentioned \\
\hline NCT03690310 & CD19 & Refractory B cell lymphoma & Allogeneic NK cells & Not mentioned & $\begin{array}{l}\text { Early } \\
\text { phase I }\end{array}$ & $\begin{array}{l}\text { Not yet } \\
\text { recruiting }\end{array}$ & Not mentioned \\
\hline NCT01974479 & CD19 & All & $\begin{array}{l}\text { Haploidentical } \\
\text { donor NK cells }\end{array}$ & Not mentioned & I & Suspended & Singapore \\
\hline NCT00995137 & CD19 & All & $\begin{array}{l}\text { Expanded donor } \\
\text { NK cells }\end{array}$ & Not mentioned & 1 & Completed & Memphis, TN, USA \\
\hline
\end{tabular}

Therefore, IL-15 as an activator of NK cells can be safely administered to patients with malignant and poorprognosis/metastatic cancers by using alternative dosing strategies such as continuous intravenous infusions and subcutaneous administration [194]. IL-12 is another pro-inflammatory cytokine with known immunomodulatory properties on NK cells and lymphoid cells. In preclinical models, administration of IL-12 augmented migratory capacity and biologic functions of NK cells [195]. However, there are still serious toxicity concerns about the clinical application of IL-12 due to its pleiotropic nature [196].

Another new approach is the incorporation of both IL-2 and IL-15 genes into the CAR constructs to be expressed and secreted within the TME. This approach has been conducted in a mouse model of Raji lymphoma. The results showed that a single infusion of
CAR.19/IL15 + CB-NK cells can control tumor progression and increase survival through improving their cancer recognition and cytotoxic activity in comparison to CAR.19/IL15-negative NK cells. These results indicate the pivotal impact of IL-15 on the antitumor activity of NK cells by improving their expansion and persistence capacity [55].

\section{Efficacy and safety}

The CAR-engineered immune effector cells (CAR-T and CAR-NK) are developed over the last two decades as the adoptive cell therapy of cancers. However, their therapeutic efficacy against solid tumors remained restricted. Consequently, some new solutions and approaches are being evaluated to improve the effectiveness of these cells. 
One of the recently developed methods for enhancing the efficacy of CAR-NK cells in a solid tumor is utilizing chemotherapy drugs in combination with CAR NK cells. Qing Zhang and his colleagues for the first time have determined the synergistic effects of Cabozantinib and EGFR-specific CAR-NK-92 cells in vitro and in vivo. Cabozantinib is a multikinase inhibitor that has repressing effects on myeloid-derived suppressor cells and Tregs and also is synergistic in combination with immunotherapies in the treatment of cancers [197, 198]. Therefore, a combination of Cabozantinib with CARNK-92 cells can be used to overcome the immunosuppressive environment of tumors. It was shown that the efficacy of the CAR-NK-92 cells increases in combination therapy with Cabozantinib against human renal cell carcinoma xenograft models [182]. On the other hand, CAR-engineered $\mathrm{T}$ cell therapy in clinical cases caused severe side effects $[199,200]$, whereas no such serious side effects were reported about CAR-NK cell therapy. For this reason, various studies have been conducted to further increase the effectiveness and safety of CAR-NK cell therapies and combination therapies [33, 164, 201].

Generally, mature NK cells have limited persistence in the tumor site, so permanent side effects are not observed. Nonetheless, there are types of NK cells with higher long-lived, such as those derived from cord blood or hematopoietic stem cells as that may cause longstanding toxicity [202]. To address this issue, today, a new method that incorporating caspase-controlled suicide vectors into CAR-NK cells has been studying, which could rapidly eradicate the transduced cells. In these regards, a recent study illustrated that applying the inducible caspase 9 (iCAS-9) suicide systems in CD19-CAR+IL15 NK cells construct causing apoptosis within $4 \mathrm{~h}$ upon addition of the matching small molecule dimerizer [55].

\section{Conclusion and perspective}

CAR-engineered NK cells can be successfully employed to improve the therapeutic outcome of cell-based cancer immunotherapy. They have been investigated in many research and also clinical trials with acceptable therapeutic results while keeping the side-effect at the minimum level in comparison to other cell-based immunotherapies. However, technical and biological challenges are still associated with gene delivery into NK cells and therefore have hindered this approach to become a routine anti-cancer treatment at the moment. There are still some difficulties in CAR delivery into NK cells and in NK cells' persistence and expansion within the body after infusion. Despite all these problems, CAR NK cells have gained much attention due to their lower safety concerns and the possibility of triggering negative immune reactions such as GvHD. NK cells can provide a homogenous, off-the-shelf, standardized cell-based medicine for the treatment of patients with resistant/ hardly treatable cancers. CAR NK cells have come to light as top anti-cancer agents with great effectiveness; however, for attaining this goal, improved CRA-NK cells with fewer side effects are required. Besides, we need better transfection methods, better than routine NK cell sources that are much more safer and efficient for CAR NK cells. Many advanced strategies including further optimization of transfer methods, novel CAR construction and delivery methods such as novel gene-editing techniques based on CRISPR/Cas9, and finally combination of CAR NK cells with other treatments such as the checkpoint inhibitors, mAbs, drugs targeting TME, and chemotherapies. These strategies may strengthen the immune system overcome cancer and open a new chapter in cancer treatment. With the improvement of CAR NK cells, it is not surprising that in the near future, CARNK cell-based immunotherapy will revolutionize the treatment of cancer.

\section{Abbreviations \\ NK: Natural killer; CAR: Chimeric antigen receptor; CAR-T: CAR-engineered T; CAR-NK: CAR-engineered NK; GVHD: Graft-versus-host disease; CRS: Cytokine release syndrome; TCR: T cell receptor; NCRs: Natural cytotoxicity receptors; ITAM: Immunoreceptor tyrosine-based activation motif; KIRs: Killer cell Ig-like receptors; ADCC: Antibody-dependent cell-mediated cytotoxicity; AML: Acute myeloid leukemia; scFv: Single-chain variable fragment; TME: Tumor microenvironment; iPSCs: Induced pluripotent stem cells; PB NK: VEGF, vascular endothelial growth factor; Tregs: Regulatory $T$ cells}

\section{Acknowledgements}

We would like to thank Mostafa Jarahian from the German Cancer Research Center Institute (DKFZ)" and Professor Yashwant Pathak (Associate Dean for Faculty Affairs, Taneja College of Pharmacy, University of South Florida, Tampa Florida, USA) for their assistance during this work.

\section{Authors' contributions}

All authors contributed to the conception and the main idea of the work. N.SHI, N.SHO, G.V, R.N.M, S.SH, and F.M drafted the main text and tables. M.A and $H, S, R$ designed the figures. F.M.KH supervised the work and provided the comments and additional scientific information. M.J, M.S.CH, L.TH, A.D, and F.B.M also reviewed and revised the text. The authors read and approved the final version of the manuscript to be published.

\section{Funding}

No funders

\section{Availability of data and materials}

Not applicable

\section{Declarations}

Ethics approval and consent to participate

Not applicable

Consent for publication

Not applicable

Competing interests

The authors declare that they have no competing interests. 


\section{Author details}

${ }^{1}$ Department of Hematology, Faculty of Medicine, Tabriz University of Medical Sciences, Tabriz, Iran. ${ }^{2}$ Immunology Research Center, Tabriz University of Medical Sciences, Tabriz, Iran. ${ }^{3}$ Department of Physiology, College of Medicine, University of Suleimanyah, Sulaymaniyah, Iraq. ${ }^{4}$ Associate professor, Department of Pharmacology, Saveetha Dental College and Hospital, Saveetha Institute of Medical and Technical Sciences, Saveetha University, Chennai, India. ${ }^{5}$ Department of Propaedeutics of Dental Diseases, I.M. Sechenov First Moscow State Medical University (Sechenov University,), Moscow, Russian Federation. ${ }^{6}$ Center for Research and Biotechnological Development, Research Department, Bolivar State University, Faculty of Agricultural Sciences, Natural Resources and the Environment, CP 020150 Guaranda, Ecuador. 'DigiCare Behavioral Research, Casa Grande, AZ, USA. ${ }^{8}$ German Cancer Research Center, Toxicology and Chemotherapy Unit (G401), 69120 Heidelberg, Germany. ${ }^{9}$ Department of Immunology, Faculty of Medicine, Zanjan University of Medical Sciences, Zanjan, Iran. ${ }^{10} \mathrm{College}$ of Veterinary Medicine, University of Sulaimani, Suleimanyah, Iraq. " Department of Pathobiology, Faculty of Veterinary Medicine, University of Shahrekord, Shahrekord, Iran. ${ }^{12}$ Department of Virology, Pasteur Institute of Iran (IPI), Tehran, Iran.

\section{Received: 15 November 2020 Accepted: 28 February 2021} Published online: 22 March 2021

\section{References}

1. Majzner RG, Mackall CL. Clinical lessons learned from the first leg of the CAR T cell journey. Nat Med. 2019;25:1341-55.

2. June $\mathrm{CH}, \mathrm{O}^{\prime}$ Connor RS, Kawalekar OU, Ghassemi S, Milone MC. CAR T cell immunotherapy for human cancer. Science (New York, N.Y.). 2018; 359:1361-5.

3. Ribas A, Wolchok JD. Cancer immunotherapy using checkpoint blockade. Science (New York, N.Y.). 2018;359:1350-5.

4. Maoz M, Devir M, Inbar M, Inbar-Daniel Z, Sherill-Rofe D, Bloch I, Meir K, Edelman D, Azzam S, Nechushtan H, Maimon O, Uziely B, Kadouri L, Sonnenblick A, Eden A, Peretz T, Zick A. Clinical implications of subgrouping HER2 positive tumors by amplicon structure and co-amplified genes. Sci Rep. 2019:9:18795.

5. Ansell SM, Lesokhin AM, Borrello I, Halwani A, Scott EC, Gutierrez M, Schuster SJ, Millenson MM, Cattry D, Freeman GJ, Rodig SJ, Chapuy B, Ligon AH, Zhu L, Grosso JF, Kim SY, Timmerman JM, Shipp MA, Armand P. PD-1 blockade with nivolumab in relapsed or refractory Hodgkin's lymphoma. N Engl J Med. 2015;372:311-9.

6. Xu-Monette ZY, Zhou J, Young KH. PD-1 expression and clinical PD-1 blockade in B-cell lymphomas. Blood. 2018;131:68-83.

7. Zhang Q, Bi J, Zheng X, Chen Y, Wang H, Wu W, Wang Z, Wu Q, Peng H, Wei H. Blockade of the checkpoint receptor TIGIT prevents NK cell exhaustion and elicits potent anti-tumor immunity. Nat Immunol. 2018;19: 723-32.

8. Kim N, Kim HS. Targeting checkpoint receptors and molecules for therapeutic modulation of natural killer cells. Front Immunol. 2018;9:2041.

9. Zhang C, Liu Y. Targeting NK cell checkpoint receptors or molecules for cancer immunotherapy. Front Immunol. 2020;111:1295.

10. Akbari M, Shomali N, Faraji A, Shanehbandi D, Asadi M, Mokhtarzadeh A Shabani A, Baradaran B. CD133: an emerging prognostic factor and therapeutic target in colorectal cancer. Cell Biol Int. 2020:44:368-80.

11. Khan M, Arooj S, Wang H. NK cell-based immune checkpoint inhibition. Front Immunol. 2020;11:167.

12. Cao $Y$, Wang $X$, Jin T, Tian $Y$, Dai C, Widarma C, Song R, Xu F. Immune checkpoint molecules in natural killer cells as potential targets for cancer immunotherapy. Signal Transduct Target Ther. 2020;5:1-19.

13. Spiess C, Zhai Q, Carter PJ. Alternative molecular formats and therapeutic applications for bispecific antibodies. Mol Immunol. 2015;67:95-106.

14. Goebeler ME, Knop S, Viardot A, Kufer P, Topp MS, Einsele H, Noppeney R, Hess G, Kallert S, Mackensen A, Rupertus K, Kanz L, Libicher M, Nagorsen D, Zugmaier G, Klinger M, Wolf A, Dorsch B, Quednau BD, Schmidt M, Scheele J, Baeuerle PA, Leo E, Bargou RC. Bispecific T-cell engager (BiTE) antibody construct blinatumomab for the treatment of patients with relapsed/ refractory non-Hodgkin lymphoma: final results from a phase i study. J Clin Oncol. 2016;34:1104-11.

15. Viardot A, Goebeler ME, Hess G, Neumann S, Pfreundschuh M, Adrian N Zettl F, Libicher M, Sayehli C, Stieglmaier J, Zhang A, Nagorsen D, Bargou
RC. Phase 2 study of the bispecific T-cell engager (BiTE) antibody blinatumomab in relapsed/refractory diffuse large B-cell lymphoma. Blood. 2016;127:1410-6.

16. Bailey SR, Maus MV. Gene editing for immune cell therapies. Nat Biotechnol. 2019;37:1425-34.

17. Hu Y, Tian ZG, Zhang C. Chimeric antigen receptor (CAR)-transduced natural killer cells in tumor immunotherapy. Acta Pharmacol Sin. 2018;39:167-76.

18. Rezvani K, Rouce R, Liu E, Shpall E. Engineering natural killer cells for cancer immunotherapy. Mol Ther. 2017;25:1769-81.

19. Porter DL, Hwang WT, Frey NV, Lacey SF, Shaw PA, Loren AW, Bagg A, Marcucci KT, Shen A, Gonzalez V, Ambrose D, Grupp SA, Chew A, Zheng Z, Milone MC, Levine BL, Melenhorst JJ, June $\mathrm{CH}$. Chimeric antigen receptor $\mathrm{T}$ cells persist and induce sustained remissions in relapsed refractory chronic lymphocytic leukemia. Sci Transl Med. 2015;7:303ra139.

20. Lee DW, Kochenderfer JN, Stetler-Stevenson M, Cui YK, Delbrook C, Feldman SA, Fry TJ, Orentas R, Sabatino M, Shah NN, Steinberg SM, Stroncek D, Tschernia N, Yuan C, Zhang H, Zhang L, Rosenberg SA, Wayne AS, Mackall $\mathrm{CL}$. T cells expressing CD19 chimeric antigen receptors for acute lymphoblastic leukaemia in children and young adults: a phase 1 doseescalation trial. Lancet (London, England). 2015;385:517-28.

21. Maude SL, Frey N, Shaw PA, Aplenc R, Barrett DM, Bunin NJ, Chew A, Gonzalez VE, Zheng Z, Lacey SF, Mahnke YD, Melenhorst JJ, Rheingold SR, Shen A, Teachey DT, Levine BL, June CH, Porter DL, Grupp SA. Chimeric antigen receptor T cells for sustained remissions in leukemia. N Engl J Med. 2014;371:1507-17

22. Davila ML, Riviere I, Wang X, Bartido S, Park J, Curran K, Chung SS, Stefanski J, Borquez-Ojeda O, Olszewska M, Qu J, Wasielewska T, He Q, Fink M, Shinglot H, Youssif M, Satter M, Wang Y, Hosey J, Quintanilla H, Halton E, Bernal Y, Bouhassira DC, Arcila ME, Gonen M, Roboz GJ, Maslak P, Douer D, Frattini MG, Giralt S, Sadelain M, Brentjens R. Efficacy and toxicity management of 19-28z CAR T cell therapy in B cell acute lymphoblastic leukemia. Sci Transl Med. 2014;6:224ra225.

23. Brentjens RJ, Davila ML, Riviere I, Park J, Wang X, Cowell LG, Bartido S, Stefanski J, Taylor C, Olszewska M, Borquez-Ojeda O, Qu J, Wasielewska T, He Q, Bernal Y, Rijo IV, Hedvat C, Kobos R, Curran K, Steinherz P, Jurcic J, Rosenblat T, Maslak P, Frattini M, Sadelain M. CD19-targeted T cells rapidly induce molecular remissions in adults with chemotherapy-refractory acute lymphoblastic leukemia. Sci Transl Med. 2013;5:177ra138.

24. Klingemann $\mathrm{H}$, Boissel $\mathrm{L}$, Toneguzzo F. Natural killer cells for immunotherapy-advantages of the NK-92 cell line over blood NK cells. Front Immunol. 2016;7:91.

25. Luo Y, Chang L-J, Hu Y, Dong L, Wei G, Huang H. First-in-man CD123specific chimeric antigen receptor-modified T cells for the treatment of refractory acute myeloid leukemia. Am Soc Hematol. 2015;126:3778.

26. Ritchie DS, Neeson PJ, Khot A, Peinert S, Tai T, Tainton K, Chen K, Shin M, Wall DM, Honemann D, Gambell P, Westerman DA, Haurat J, Westwood JA, Scott AM, Kravets L, Dickinson M, Trapani JA, Smyth MJ, Darcy PK, Kershaw MH, Prince HM. Persistence and efficacy of second generation CAR T cell against the LeY antigen in acute myeloid leukemia. Mol Ther. 2013;21:2122-9.

27. Wang QS, Wang Y, Lv HY, Han QW, Fan H, Guo B, Wang LL, Han WD. Treatment of CD33-directed chimeric antigen receptor-modified T cells in one patient with relapsed and refractory acute myeloid leukemia. Mol Ther. 2015;23:184-91.

28. Tokarew N, Ogonek J, Endres S, von Bergwelt-Baildon M, Kobold S. Teaching an old dog new tricks: next-generation CAR T cells. Br J Cancer. 2019;120:26-37.

29. Majzner RG, Mackall CL. Tumor antigen escape from CAR T-cell therapy. Cancer Discov. 2018;8:1219-26.

30. Brudno JN, Kochenderfer JN. Toxicities of chimeric antigen receptor T cells: recognition and management. Blood. 2016;127:3321-30.

31. Rezvani K. Adoptive cell therapy using engineered natural killer cells. Bone Marrow Transplant. 2019;54:785-8.

32. Mehta RS, Rezvani K. Chimeric antigen receptor expressing natural killer cells for the immunotherapy of cancer. Front Immunol. 2018;9:283.

33. Daher M, Rezvani K. Next generation natural killer cells for cancer immunotherapy: the promise of genetic engineering. Curr Opin Immunol. 2018:51:146-53.

34. Childs RW, Carlsten M. Therapeutic approaches to enhance natural killer cell cytotoxicity against cancer: the force awakens. Nat Rev Drug Discov. 2015; 14:487-98. 
35. Souza-Fonseca-Guimaraes F, Cursons J, Huntington ND. The emergence of natural killer cells as a major target in cancer immunotherapy. Trends Immunol. 2019;40:142-58.

36. Hermanson DL, Kaufman DS. Utilizing chimeric antigen receptors to direct natural killer cell activity. Front Immunol. 2015;6:195.

37. Geller MA, Cooley S, Judson PL, Ghebre R, Carson LF, Argenta PA, Jonson AL, Panoskaltsis-Mortari A, Curtsinger J, McKenna D. A phase II study of allogeneic natural killer cell therapy to treat patients with recurrent ovarian and breast cancer. Cytotherapy. 2011;13:98-107.

38. Kiessling R, Klein E, Wigzell H. "Natural" killer cells in the mouse. I. Cytotoxic cells with specificity for mouse Moloney leukemia cells. Specificity and distribution according to genotype. Eur J Immunol. 1975;5:112-7.

39. Kiessling R, Klein E, Pross H, Wigzell H. "Natural" killer cells in the mouse. II. Cytotoxic cells with specificity for mouse Moloney leukemia cells. Characteristics of the killer cell. Eur J Immunol. 1975;5:117-21.

40. Orange JS. Natural killer cell deficiency. J Allergy Clin Immunol. 2013;132: 515-25

41. Herberman RB, Nunn ME, Lavrin DH. Natural cytotoxic reactivity of mouse lymphoid cells against syngeneic and allogeneic tumors. I. Distribution of reactivity and specificity. Int J Cancer. 1975;16:216-29.

42. Ada G. Twenty years into the saga of MHC-restriction. Immunol Cell Biol. 1994;72:447-54.

43. Fehniger TA, Cooper MA, Nuovo GJ, Cella M, Facchetti F, Colonna M, Caligiuri MA. CD56bright natural killer cells are present in human lymph nodes and are activated by T cell-derived IL-2: a potential new link between adaptive and innate immunity. Blood. 2003;101:3052-7.

44. Robinson MW, Harmon C, O'Farrelly C. Liver immunology and its role in inflammation and homeostasis. Cell Mol Immunol. 2016;13:267.

45. Oberschmidt O, Kloess S, Koehl U. Redirected primary human chimeric antigen receptor natural killer cells as an "off-the-shelf immunotherapy" for improvement in cancer treatment. Front Immunol. 2017;8:654.

46. Morice WG. The immunophenotypic attributes of NK cells and NK-cell lineage lymphoproliferative disorders. Am J Clin Pathol. 2007;127:881-6.

47. Campbell KS, Hasegawa J. Natural killer cell biology: an update and future directions. J Allergy Clin Immunol. 2013;132:536-44.

48. Montaldo E, Vacca P, Vitale C, Moretta F, Locatelli F, Mingari MC, Moretta L. Human innate lymphoid cells. Immunol Lett. 2016;179:2-8.

49. De Maria A, Bozzano F, Cantoni C, Moretta L. Revisiting human natural killer cell subset function revealed cytolytic CD56dimCD16+ NK cells as rapid producers of abundant IFN- $\gamma$ on activation. Proc Natl Acad Sci. 2011;108: 728-32

50. Cooper MA, Fehniger TA, Caligiuri MA. The biology of human natural killercell subsets. Trends Immunol. 2001;22:633-40.

51. Romee R, Leong JW, Fehniger TA. Utilizing cytokines to function-enable human NK cells for the immunotherapy of cancer. Scientifica. 2014;2014 205796.

52. Poli $A$, Michel $T$, Thérésine $M$, Andrès $E$, Hentges $F$, Zimmer J. CD56bright natural killer (NK) cells: an important NK cell subset. Immunology. 2009;126: 458-65

53. Fauriat C, Long EO, Ljunggren $\mathrm{H}-\mathrm{G}$, Bryceson $\mathrm{YT}$. Regulation of human NKcell cytokine and chemokine production by target cell recognition. Blood. 2010;115:2167-76.

54. Vivier E, Tomasello E, Baratin M, Walzer T, Ugolini S. Functions of natural killer cells. Nat Immunol. 2008;9:503.

55. Liu E, Tong Y, Dotti G, Shaim H, Savoldo B, Mukherjee M, Orange J, Wan X, Lu X, Reynolds A. Cord blood NK cells engineered to express IL-15 and a CD19-targeted CAR show long-term persistence and potent antitumor activity. Leukemia. 2018;32:520.

56. Kumar S. Natural killer cell cytotoxicity and its regulation by inhibitory receptors. Immunology. 2018;154:383-93.

57. Fang F, Xiao W, Tian Z. NK cell-based immunotherapy for cancer. Semin Immunol. 2017:31:37-54.

58. Li Y, Yin J, Li T, Huang S, Yan H, Leavenworth J, Wang X. NK cell-based cancer immunotherapy: from basic biology to clinical application. Sci China Life Sci. 2015;58:1233-45

59. Cichocki F, Lenvik T, Sharma N, Yun G, Anderson SK, Miller JS. Cutting edge: KIR antisense transcripts are processed into a 28-base PIWI-like RNA in human NK cells. J Immunol (Baltimore, Md. : 1950). 2010;185:2009-12.

60. Wight A, Mahmoud AB, Scur M, Tu MM, Rahim MMA, Sad S, Makrigiannis AP. Critical role for the Ly49 family of class I MHC receptors in adaptive natural killer cell responses. Proc Natl Acad Sci. 2018;115:11579-84.
61. Braud VM, Allan DS, O'Callaghan CA, Söderström K, D'Andrea A, Ogg GS, Lazetic S, Young NT, Bell Jl, Phillips JH. HLA-E binds to natural killer cell receptors CD94/NKG2A, B and C. Nature. 1998;391:795.

62. Farag SS, Caligiuri MA. Human natural killer cell development and biology. Blood Rev. 2006;20:123-37.

63. Moretta A, Bottino C, Vitale M, Pende D, Cantoni C, Mingari MC, Biassoni R, Moretta L. Activating receptors and coreceptors involved in human natural killer cell-mediated cytolysis. Annu Rev Immunol. 2001;19:197-223.

64. Cheng M, Chen Y, Xiao W, Sun R, Tian Z. NK cell-based immunotherapy for malignant diseases. Cell Mol Immunol. 2013;10:230.

65. Arnon TI, Markel G, Mandelboim O. Tumor and viral recognition by natural killer cells receptors. Semin Cancer Biol. 2006;16:348-58.

66. Arai $\mathrm{S}$, Klingemann $\mathrm{H}-\mathrm{G}$. Natural killer cells: can they be useful as adoptive immunotherapy for cancer? Expert Opin Biol Ther. 2005;5:163-72.

67. Ames E, Murphy WJ. Advantages and clinical applications of natural killer cells in cancer immunotherapy. Cancer Immunol Immunother. 2014;63:21-8.

68. Orange JS. Formation and function of the lytic NK-cell immunological synapse. Nat Rev Immunol. 2008:8:713.

69. Koch J, Steinle A, Watzl C, Mandelboim O. Activating natural cytotoxicity receptors of natural killer cells in cancer and infection. Trends Immunol. 2013;34:182-91.

70. Carlsten M, Childs RW. Genetic manipulation of NK cells for cancer immunotherapy: techniques and clinical implications. Front Immunol. 2015; $6: 266$.

71. Glienke W, Esser R, Priesner C, Suerth JD, Schambach A, Wels WS, Grez M, Kloess S, Arseniev L, Koehl U. Advantages and applications of CARexpressing natural killer cells. Front Pharmacol. 2015;6:21.

72. Guillerey C, Huntington ND, Smyth MJ. Targeting natural killer cells in cancer immunotherapy. Nat Immunol. 2016;17:1025.

73. Liu D, Tian S, Zhang K, Xiong W, Lubaki NM, Chen Z, Han W. Chimeric antigen receptor (CAR)-modified natural killer cell-based immunotherapy and immunological synapse formation in cancer and HIV. Protein Cell. 2017; 8:861-77.

74. Zenere G, Olwenyi OA, Byrareddy SN, Braun SE. Optimizing intracellular signaling domains for CAR NK cells in HIV immunotherapy: a comprehensive review. Drug Discov Today. 2019;24:983-91.

75. Boissel L, Betancur M, Wels WS, Tuncer $H$, Klingemann $H$. Transfection with mRNA for CD19 specific chimeric antigen receptor restores NK cell mediated killing of CLL cells. Leuk Res. 2009;33:1255-9.

76. Romanski A, Uherek C, Bug G, Seifried E, Klingemann H, Wels WS, Ottmann OG, Tonn T. CD 19-CAR engineered NK-92 cells are sufficient to overcome NK cell resistance in B-cell malignancies. J Cell Mol Med. 2016;20:1287-94.

77. Geyer MB, Brentjens RJ. Current clinical applications of chimeric antigen receptor (CAR) modified T cells. Cytotherapy. 2016;18:1393-409.

78. Müller N, Michen S, Tietze S, Töpfer K, Schulte A, Lamszus K, Schmitz M, Schackert G, Pastan I, Temme A. Engineering NK cells modified with an EGFRvIll-specific chimeric antigen receptor to overexpress CXCR4 improves immunotherapy of CXCL12/SDF-1a-secreting glioblastoma. J Immunother (Hagerstown, Md.: 1997). 2015;38:197.

79. Imai C, Iwamoto S, Campana D. Genetic modification of primary natural killer cells overcomes inhibitory signals and induces specific killing of leukemic cells. Blood. 2005;106:376-83.

80. Töpfer K, Cartellieri M, Michen S, Wiedemuth R, Müller N, Lindemann D, Bachmann M, Füssel M, Schackert G, Temme A. DAP12-based activating chimeric antigen receptor for NK cell tumor immunotherapy. J Immunol. 2015;194:3201-12.

81. Olson JA, Leveson-Gower DB, Gill S, Baker J, Beilhack A, Negrin RS. NK cells mediate reduction of GVHD by inhibiting activated, alloreactive T cells while retaining GVT effects. Blood. 2010;115:4293-301.

82. Ruggeri L, Capanni M, Urbani E, Perruccio K, Shlomchik WD, Tosti A, Posati S, Rogaia D, Frassoni F, Aversa F. Effectiveness of donor natural killer cell alloreactivity in mismatched hematopoietic transplants. Science (New York, N.Y.). 2002;295:2097-100.

83. Fitzgerald JC, Weiss SL, Maude SL, Barrett DM, Lacey SF, Melenhorst JJ, Shaw $\mathrm{P}$, Berg RA, June $\mathrm{CH}$, Porter DL. Cytokine release syndrome after chimeric antigen receptor $T$ cell therapy for acute lymphoblastic leukemia. Crit Care Med. 2017;45:e124.

84. Neelapu SS, Tummala S, Kebriaei P, Wierda W, Gutierrez C, Locke FL, Komanduri KV, Lin Y, Jain N, Daver N. Chimeric antigen receptor T-cell therapy-assessment and management of toxicities. Nat Rev Clin Oncol. 2018;15:47. 
85. Chiossone L, Dumas P-Y, Vienne M, Vivier E. Natural killer cells and other innate lymphoid cells in cancer. Nat Rev Immunol. 2018:1.

86. Eguizabal C, Zenarruzabeitia O, Monge J, Santos S, Vesga MA, Maruri N, Arrieta A, Riñón M, Tamayo-Orbegozo E, Amo L. Natural killer cells for cancer immunotherapy: pluripotent stem cells-derived NK cells as an immunotherapeutic perspective. Front Immunol. 2014;5:439.

87. Nazimuddin F, Finklestein JM, Gupta M, Kulikovskaya I, Ambrose DE, Gill S, Lacey SF, Zheng Z, Melenhorst JJ, Levine BL. Long-term functional persistence, B cell aplasia and anti-leukemia efficacy in refractory B cell malignancies following $T$ cell immunotherapy using CAR-redirected $T$ cells targeting CD19. Am Soc Hematol. 2013;122:163.

88. Kim S, Poursine-Laurent J, Truscott SM, Lybarger L, Song Y-J, Yang L, French AR, Sunwoo JB, Lemieux S, Hansen TH. Licensing of natural killer cells by host major histocompatibility complex class I molecules. Nature. 2005;436:709.

89. Miller JS, Soignier Y, Panoskaltsis-Mortari A, McNearney SA, Yun GH, Fautsch SK, McKenna D, Le C, Defor TE, Burns LJ. Successful adoptive transfer and in vivo expansion of human haploidentical NK cells in patients with cancer. Blood. 2005;105:3051-7.

90. Alcantara M, Tesio M, June CH, Houot R. CAR T-cells for T-cell malignancies: challenges in distinguishing between therapeutic, normal, and neoplastic Tcells. Leukemia. 2018:1.

91. Zhang J, Zheng H, Diao Y. Natural killer cells and current applications of chimeric antigen receptor-modified NK-92 cells in tumor immunotherapy. Int J Mol Sci. 2019;20:317

92. Gong J-H, Maki G, Klingemann $\mathrm{H}$. Characterization of a human cell line (NK92) with phenotypical and functional characteristics of activated natural killer cells. Leukemia. 1994;8:652-8.

93. Maki G, Klingemann H-G, Martinson JA, Tam YK. Factors regulating the cytotoxic activity of the human natural killer cell line, NK-92. J Hematother Stem Cell Res. 2001;10:369-83.

94. MacLeod RA, Nagel S, Kaufmann M, Greulich-Bode K, Drexler HG. MulticolorFISH analysis of a natural killer cell line (NK-92). Leuk Res. 2002;26:1027-33.

95. Burga RA, Nguyen T, Zulovich J, Madonna S, Ylisastigui L, Fernandes R, Yvon E. Improving efficacy of cancer immunotherapy by genetic modification of natural killer cells. Cytotherapy. 2016;18:1410-21.

96. Arai $S$, Meagher $R$, Swearingen M, Myint H, Rich E, Martinson J, Klingemann $\mathrm{H}$. Infusion of the allogeneic cell line NK-92 in patients with advanced renal cell cancer or melanoma: a phase I trial. Cytotherapy. 2008;10:625-32.

97. Tonn T, Schwabe D, Klingemann HG, Becker S, Esser R, Koehl U, Suttorp M, Seifried E, Ottmann OG, Bug G. Treatment of patients with advanced cancer with the natural killer cell line NK-92. Cytotherapy. 2013;15:1563-70.

98. Chen KH, Wada M, Firor AE, Pinz KG, Jares A, Liu H, Salman H, Golightly M, Lan $F$, Jiang $X$. Novel anti-CD3 chimeric antigen receptor targeting of aggressive $T$ cell malignancies. Oncotarget. 2016;7:56219.

99. Tam YK, Maki G, Miyagawa B, Hennemann B, Tonn T, Klingemann HG. Characterization of genetically altered, interleukin 2-independent natural killer cell lines suitable for adoptive cellular immunotherapy. Hum Gene Ther. 1999;10:1359-73.

100. Woll PS, Martin CH, Miller JS, Kaufman DS. Human embryonic stem cellderived NK cells acquire functional receptors and cytolytic activity. J Immunol. 2005;175:5095-103.

101. Woll PS, Grzywacz B, Tian X, Marcus RK, Knorr DA, Verneris MR, Kaufman DS. Human embryonic stem cells differentiate into a homogeneous population of natural killer cells with potent in vivo antitumor activity. Blood. 2009;113: 6094-101.

102. Li Y, Hermanson DL, Moriarity BS, Kaufman DS. Human iPSC-derived natural killer cells engineered with chimeric antigen receptors enhance anti-tumor activity. Cell Stem Cell. 2018;23:181-192. e185.

103. Rotolo R, Leuci V, Donini C, Cykowska A, Gammaitoni L, Medico G, Valabrega G, Aglietta M, Sangiolo D. CAR-based strategies beyond T lymphocytes: integrative opportunities for cancer adoptive immunotherapy. Int J Mol Sci. 2019;20:2839.

104. Shaim H, Yvon E. Cord blood: a promising source of allogeneic natural killer cells for immunotherapy. Cytotherapy. 2015;17:1-2

105. Bröker K, Sinelnikov E, Gustavus D, Schumacher U, Pörtner R, Hoffmeister H, Lüth S, Dammermann W. Mass production of highly active NK cells for cancer immunotherapy in a GMP conform perfusion bioreactor. Front Bioeng Biotechnol. 2019;7:194.

106. Becker PS, Suck G, Nowakowska P, Ullrich E, Seifried E, Bader P, Tonn T, Seidl C. Selection and expansion of natural killer cells for NK cell-based immunotherapy. Cancer Immunol Immunother. 2016;65:477-84.
107. Cho D, Campana D. Expansion and activation of natural killer cells for cancer immunotherapy. Korean J Lab Med. 2009;29:89-96.

108. Peighambarzadeh F, Najafalizadeh A, Esmaeil N, Rezaei A, Ashrafi F, Hakemi MG. Optimization of in vitro expansion and activation of human natural killer cells against breast cancer cell line. Avicenna J Med Biotechnol. 2020; 12:17.

109. Boissel L, Tuncer HH, Betancur M, Wolfberg A, Klingemann H. Umbilical cord mesenchymal stem cells increase expansion of cord blood natural killer cells. Biol Blood Marrow Transplant. 2008;14:1031-8.

110. Bae DS, Lee JK. Development of NK cell expansion methods using feeder cells from human myelogenous leukemia cell line. Blood Res. 2014;49:154-61.

111. Matosevic S. Viral and nonviral engineering of natural killer cells as emerging adoptive cancer immunotherapies. J Immunol Res. 2018;2018: 4054815.

112. Poletti $V$, Mavilio F. Interactions between retroviruses and the host cell genome. Mol Ther Methods Clin Dev. 2018;8:31-41.

113. Tumaini B, Lee DW, Lin T, Castiello L, Stroncek DF, Mackall C, Wayne A, Sabatino M. Simplified process for the production of anti-CD19-CARengineered T cells. Cytotherapy. 2013;15:1406-15.

114. van Til NP, Wagemaker G. Lentiviral gene transduction of mouse and human hematopoietic stem cells. Methods Mol Biol (Clifton, N.J.). 2014;1185: 311-9.

115. De Meyer SF, Vanhoorelbeke K, Chuah MK, Pareyn I, Gillijns V, Hebbel RP, Collen D, Deckmyn H, VandenDriessche T. Phenotypic correction of von Willebrand disease type 3 blood-derived endothelial cells with lentiviral vectors expressing von Willebrand factor. Blood. 2006;107:4728-36.

116. Hacein-Bey-Abina S, Garrigue A, Wang GP, Soulier J, Lim A, Morillon E, Clappier E, Caccavelli L, Delabesse E, Beldjord K, Asnafi V, Maclntyre E, Cortivo LD, Radford I, Brousse N, Sigaux F, Moshous D, Hauer J, Borkhardt A, Belohradsky BH, Wintergerst U, Velez MC, Leiva L, Sorensen R, Wulffraat N, Blanche S, Bushman FD, Fischer A, Cavazzana-Calvo M. Insertional oncogenesis in 4 patients after retrovirus-mediated gene therapy of SCIDX1. J Clin Investig. 2008;118:3132-42.

117. Howe SJ, Mansour MR, Schwarzwaelder K, Bartholomae C, Hubank M, Kempski H, Brugman MH, Pike-Overzet K, Chatters SJ, de Ridder D, Gilmour KC, Adams S, Thornhill SI, Parsley KL, Staal FJ, Gale RE, Linch DC, Bayford J, Brown L, Quaye M, Kinnon C, Ancliff P, Webb DK, Schmidt M, von Kalle C, Gaspar HB, Thrasher AJ. Insertional mutagenesis combined with acquired somatic mutations causes leukemogenesis following gene therapy of SCIDX1 patients. J Clin Invest. 2008;118:3143-50.

118. Braun CJ, Boztug K, Paruzynski A, Witzel M, Schwarzer A, Rothe M, Modlich U, Beier R, Gohring G, Steinemann D, Fronza R, Ball CR, Haemmerle R, Naundorf S, Kuhlcke K, Rose M, Fraser C, Mathias L, Ferrari R, Abboud MR, Al-Herz W, Kondratenko I, Marodi L, Glimm H, Schlegelberger B, Schambach A, Albert MH, Schmidt M, von Kalle C, Klein C. Gene therapy for WiskottAldrich syndrome--long-term efficacy and genotoxicity. Sci Transl Med. 2014;6:227ra233.

119. Boissel L, Betancur M, Lu W, Wels WS, Marino T, Van Etten RA, Klingemann $\mathrm{H}$. Comparison of mRNA and lentiviral based transfection of natural killer cells with chimeric antigen receptors recognizing lymphoid antigens. Leuk Lymphoma. 2012;53:958-65.

120. Wilber A, Linehan JL, Tian X, Woll PS, Morris JK, Belur LR, Mclvor RS, Kaufman DS. Efficient and stable transgene expression in human embryonic stem cells using transposon-mediated gene transfer. Stem Cells (Dayton, Ohio). 2007;25:2919-27.

121. Kebriaei $P$, Singh $H$, Huls MH, Figliola MJ, Bassett R, Olivares $S$, Jena B, Dawson MJ, Kumaresan PR, Su S, Maiti S, Dai J, Moriarity B, Forget MA, Senyukov V, Orozco A, Liu T, McCarty J, Jackson RN, Moyes JS, Rondon G, Qazilbash M, Ciurea S, Alousi A, Nieto Y, Rezvani K, Marin D, Popat U, Hosing C, Shpall EJ, Kantarjian H, Keating M, Wierda W, Do KA, Largaespada DA, Lee DA, Hackett PB, Champlin RE, Cooper LJ. Phase I trials using Sleeping Beauty to generate CD19-specific CAR T cells. J Clin Investig. 2016;126:3363-76.

122. Al-Dosari MS, Gao X. Nonviral gene delivery: principle, limitations, and recent progress. AAPS J. 2009;11:671-81.

123. Begum AA, Toth I, Hussein WM, Moyle PM. Advances in targeted gene delivery. Curr Drug Deliv. 2019;16:588-608.

124. Gehl J, Frandsen SK. Electroporation-based therapies in the treatment of cancer. Ugeskrift Laeger. 2019;181:V08190461.

125. Shi J, Ma Y, Zhu J, Chen Y, Sun Y, Yao Y, Yang Z, Xie J. A review on electroporation-based intracellular delivery. Molecules (Basel, Switzerland). 2018;23:3044 
126. Shomali N, Gharibi T, Vahedi G, Mohammed RN, Mohammadi H, Salimifard $\mathrm{S}$, Marofi F. Mesenchymal stem cells as carrier of the therapeutic agent in the gene therapy of blood disorders. J Cell Physiol. 2020;235:4120-34.

127. Yarmush ML, Golberg A, Sersa G, Kotnik T, Miklavcic D. Electroporationbased technologies for medicine: principles, applications, and challenges. Annu Rev Biomed Eng. 2014;16:295-320.

128. Li L, Liu LN, Feller S, Allen C, Shivakumar R, Fratantoni J, Wolfraim LA, Fujisaki H, Campana D, Chopas N. Expression of chimeric antigen receptors in natural killer cells with a regulatory-compliant non-viral method. Cancer Gene Ther. 2010;17:147.

129. Shimasaki N, Fujisaki H, Cho D, Masselli M, Lockey T, Eldridge P, Leung W, Campana D. A clinically adaptable method to enhance the cytotoxicity of natural killer cells against B-cell malignancies. Cytotherapy. 2012;14:830-40

130. Han J, Chu J, Chan WK, Zhang J, Wang Y, Cohen JB, Victor A, Meisen WH, Kim S-h, Grandi P. CAR-engineered NK cells targeting wild-type EGFR and EGFRvIll enhance killing of glioblastoma and patient-derived glioblastoma stem cells. Sci Rep. 2015;5:11483.

131. Elmacken M, Awasthi A, Ayello J, van de Ven C, Luo W, Liao Y, Riddell S, Cairo MS. Neuroblastoma and Ewing's sarcoma associated with ROR1 expression can be effectively targeted with NK cells modified to express an anti ROR1 chimeric antigen receptor. Biol Blood Marrow Transplant. 2015;21: S95-7.

132. Oberoi P, Wels WS. Arming NK cells with enhanced antitumor activity: CARs and beyond. Oncoimmunology. 2013;2:e25220.

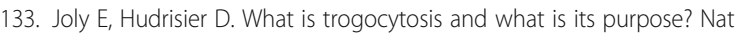
Immunol. 2003;4:815.

134. Cho F-N, Chang T-H, Shu C-W, Ko M-C, Liao S-K, Wu K-H, Yu M-S, Lin S-J, Hong $\mathrm{Y}-\mathrm{C}$, Chen $\mathrm{C}-\mathrm{H}$. Enhanced cytotoxicity of natural killer cells following the acquisition of chimeric antigen receptors through trogocytosis. PLoS One. 2014;9:e109352.

135. Tipanee J, Chai YC, VandenDriessche T, Chuah MK. Preclinical and clinical advances in transposon-based gene therapy. Biosci Rep. 2017;37.

136. Bishop DC, Xu N, Tse B, O'Brien TA, Gottlieb DJ, Dolnikov A, Micklethwaite KP. PiggyBac-engineered T cells expressing CD19-specific CARs that lack $\operatorname{lgG} 1 \mathrm{fC}$ spacers have potent activity against B-ALL xenografts. Mol Ther. 2018;26:1883-95.

137. Wang J, Lupo KB, Chambers AM, Matosevic S. Purinergic targeting enhances immunotherapy of CD73(+) solid tumors with piggyBacengineered chimeric antigen receptor natural killer cells. J Immunother Cancer. 2018;6:136.

138. Boissel L, Betancur-Boissel M, Lu W, Krause DS, Van Etten RA, Wels WS, Klingemann $\mathrm{H}$. Retargeting NK-92 cells by means of CD19- and CD20-specific chimeric antigen receptors compares favorably with antibody-dependent cellular cytotoxicity. Oncoimmunology. 2013;2: e26527.

139. De Oliveira SN, Ryan C, Giannoni F, Hardee CL, Tremcinska I, Katebian B, Wherley J, Sahaghian A, Tu A, Grogan T, Elashoff D, Cooper LJ, Hollis RP, Kohn DB. Modification of hematopoietic stem/progenitor cells with CD19specific chimeric antigen receptors as a novel approach for cancer immunotherapy. Hum Gene Ther. 2013;24:824-39.

140. Müller T, Uherek C, Maki G, Chow KU, Schimpf A, Klingemann H-G, Tonn T, Wels WS. Expression of a CD20-specific chimeric antigen receptor enhances cytotoxic activity of NK cells and overcomes NK-resistance of lymphoma and leukemia cells. Cancer Immunol Immunother. 2008;57:411-23.

141. Ravi D, Sarkar S, Purvey S, Passero F, Beheshti A, Chen Y, Mokhtar M, David $K$, Konry T, Evens AM. Interaction kinetics with transcriptomic and secretory responses of CD19-CAR natural killer-cell therapy in CD20 resistant nonhodgkin lymphoma. Leukemia. 2020;34:1291-304.

142. Oelsner S, Waldmann A, Billmeier A, Röder J, Lindner A, Ullrich E, Marschalek R, Dotti G, Jung G, Große-Hovest L. Genetically engineered CAR NK cells display selective cytotoxicity against FLT3-positive B-ALL and inhibit in vivo leukemia growth. Int J Cancer. 2019;145:1935-45.

143. Pinz KG, Yakaboski $E$, Jares A, Liu H, Firor AE, Chen KH, Wada M, Salman $H$, Tse W, Hagag N. Targeting T-cell malignancies using anti-CD4 CAR NK-92 cells. Oncotarget. 2017:8:112783.

144. Kyle RA, Rajkumar SV. Multiple myeloma. Blood. 2008;111:2962-72.

145. Chu J, Deng Y, Benson DM, He S, Hughes T, Zhang J, Peng Y, Mao H, Yi L, Ghoshal K, He X, Devine SM, Zhang X, Caligiuri MA, Hofmeister CC, Yu J. CS1-specific chimeric antigen receptor (CAR)-engineered natural killer cells enhance in vitro and in vivo antitumor activity against human multiple myeloma. Leukemia. 2014;28:917-27.
146. Jiang $H$, Zhang $W$, Shang $P$, Zhang $H$, Fu W, Ye F, Zeng T, Huang $H$, Zhang X, Sun W, Man-Yuen Sze D, Yi Q, Hou J. Transfection of chimeric anti-CD138 gene enhances natural killer cell activation and killing of multiple myeloma cells. Mol Oncol. 2014;8:297-310.

147. Duffau H. Glioblastoma in 2017. Rev l'infirmiere. 2017;66:16-8.

148. Genßler S, Burger MC, Zhang C, Oelsner S, Mildenberger I, Wagner M, Steinbach JP, Wels WS. Dual targeting of glioblastoma with chimeric antigen receptor-engineered natural killer cells overcomes heterogeneity of target antigen expression and enhances antitumor activity and survival. Oncoimmunology. 2016;5:e1119354.

149. Zhang C, Burger MC, Jennewein L, Genßler S, Schönfeld K, Zeiner P, Hattingen E, Harter PN, Mittelbronn M, Tonn T. ErbB2/HER2-specific NK cells for targeted therapy of glioblastoma. J Natl Cancer Inst. 2015;108:djv375.

150. Muller N, Michen S, Tietze S, Topfer K, Schulte A, Lamszus K, Schmitz M, Schackert G, Pastan I, Temme A. Engineering NK cells modified with an EGFRvIII-specific chimeric antigen receptor to overexpress CXCR4 improves immunotherapy of CXCL12/SDF-1alpha-secreting glioblastoma. J Immunother (Hagerstown, Md. : 1997). 2015;38:197-210.

151. Topfer K, Cartellieri M, Michen S, Wiedemuth R, Muller N, Lindemann D, Bachmann M, Fussel M, Schackert G, Temme A. DAP12-based activating chimeric antigen receptor for NK cell tumor immunotherapy. J Immunol (Baltimore, Md. : 1950). 2015;194:3201-12.

152. Murakami T, Nakazawa T, Natsume A, Nishimura F, Nakamura M, Matsuda R, Omoto K, Tanaka Y, Shida Y, Park YS, Motoyama Y, Nakagawa I, Yamada S, Tamura K, Takeshima Y, Takamura Y, Wakabayashi T, Nakase H. Novel human NK cell line carrying CAR targeting EGFRvIII induces antitumor effects in glioblastoma cells. Anticancer Res. 2018;38:5049-56.

153. Zhang C, Burger MC, Jennewein L, Genssler S, Schonfeld K, Zeiner $P$, Hattingen E, Harter PN, Mittelbronn M, Tonn T, Steinbach JP, Wels WS. ErbB2/HER2-specific NK cells for targeted therapy of glioblastoma. J Natl Cancer Inst. 2016;108.

154. Subramanian J, Katta A, Masood A, Vudem DR, Kancha RK. Emergence of ERBB2 mutation as a biomarker and an actionable target in solid cancers. Oncologist. 2019;24:e1303-14.

155. Morgan RA, Yang JC, Kitano M, Dudley ME, Laurencot CM, Rosenberg SA. Case report of a serious adverse event following the administration of $\mathrm{T}$ cells transduced with a chimeric antigen receptor recognizing ERBB2. Mol Ther. 2010;18:843-51.

156. Liu X, Jiang S, Fang C, Yang S, Olalere D, Pequignot EC, Cogdill AP, Li N, Ramones M, Granda B. Affinity-tuned ErbB2 or EGFR chimeric antigen receptor $T$ cells exhibit an increased therapeutic index against tumors in mice. Cancer Res. 2015;75:3596-607.

157. Wilkie S, van Schalkwyk MC, Hobbs S, Davies DM, van der Stegen SJ, Pereira ACP, Burbridge SE, Box C, Eccles SA, Maher J. Dual targeting of ErbB2 and MUC1 in breast cancer using chimeric antigen receptors engineered to provide complementary signaling. J Clin Immunol. 2012;32:1059-70.

158. Uherek C, Tonn T, Uherek B, Becker S, Schnierle B, Klingemann HG, Wels W. Retargeting of natural killer-cell cytolytic activity to ErbB2-expressing cancer cells results in efficient and selective tumor cell destruction. Blood. 2002;100: 1265-73.

159. Schonfeld K, Sahm C, Zhang C, Naundorf S, Brendel C, Odendahl M, Nowakowska P, Bonig H, Kohl U, Kloess S, Kohler S, Holtgreve-Grez H, Jauch A, Schmidt M, Schubert R, Kuhlcke K, Seifried E, Klingemann HG, Rieger MA, Tonn T, Grez M, Wels WS. Selective inhibition of tumor growth by clonal NK cells expressing an ErbB2/HER2-specific chimeric antigen receptor. Mol Ther. 2015;23:330-8.

160. Zhang C, Oberoi P, Oelsner S, Waldmann A, Lindner A, Tonn T, Wels WS. Chimeric antigen receptor-engineered NK-92 cells: an off-the-shelf cellular therapeutic for targeted elimination of cancer cells and induction of protective antitumor immunity. Front Immunol. 2017;8:533.

161. Zhang Q, Xu J, Ding J, Liu H, Li H, Li H, Lu M, Miao Y, Wang Z, Fu Q, Zheng J. Bortezomib improves adoptive carbonic anhydrase IXspecific chimeric antigen receptormodified NK92 cell therapy in mouse models of human renal cell carcinoma. Oncol Rep. 2018:40:3714-24.

162. Zhang Q, Zhang H, Ding J, Liu H, Li H, Li H, Lu M, Miao Y, Li L, Zheng J. Combination therapy with EpCAM-CAR-NK-92 cells and regorafenib against human colorectal cancer models. J Immunol Res. 2018;2018:4263520.

163. Xia N, Haopeng P, Gong JU, Lu J, Chen Z, Zheng Y, Wang Z, Sun YU, Yang Z, Hoffman RM, Liu F. Robo1-specific CAR-NK immunotherapy enhances efficacy of (125)l seed brachytherapy in an orthotopic mouse model of human pancreatic carcinoma. Anticancer Res. 2019;39:5919-25. 
164. Chen X, Han J, Chu J, Zhang L, Zhang J, Chen C, Chen L, Wang Y, Wang H Yi L, Elder JB, Wang QE, He X, Kaur B, Chiocca EA, Yu J. A combinational therapy of EGFR-CAR NK cells and oncolytic herpes simplex virus 1 for breast cancer brain metastases. Oncotarget. 2016;7:27764-77.

165. Altvater B, Landmeier S, Pscherer S, Temme J, Schweer K, Kailayangiri S, Campana D, Juergens H, Pule M, Rossig C. 2B4 (CD244) signaling by recombinant antigen-specific chimeric receptors costimulates natural killer cell activation to leukemia and neuroblastoma cells. Clin Cancer Res. 2009; 15:4857-66.

166. Esser R, Müller T, Stefes D, Kloess S, Seidel D, Gillies SD, Aperlo-Iffland C, Huston JS, Uherek C, Schönfeld K. NK cells engineered to express a GD2-specific antigen receptor display built-in ADCC-like activity against tumour cells of neuroectodermal origin. J Cell Mol Med. 2012; 16:569-81.

167. Kailayangiri S, Altvater B, Spurny C, Jamitzky S, Schelhaas S, Jacobs AH, Wiek C, Roellecke K, Hanenberg H, Hartmann W. Targeting Ewing sarcoma with activated and GD2-specific chimeric antigen receptor-engineered human NK cells induces upregulation of immune-inhibitory HLA-G. Oncoimmunology. 2017;6:e1250050.

168. Oelsner S, Wagner J, Friede ME, Pfirrmann V, Genssler S, Rettinger $E$, Buchholz CJ, Pfeifer H, Schubert R, Ottmann OG, Ullrich E, Bader P, Wels WS. Chimeric antigen receptor-engineered cytokine-induced killer cells overcome treatment resistance of pre-B-cell acute lymphoblastic leukemia and enhance survival. Int J Cancer. 2016;139:1799-809.

169. Oelsner S, Friede ME, Zhang C, Wagner J, Badura S, Bader P, Ullrich E, Ottmann OG, Klingemann H, Tonn T. Continuously expanding CAR NK-92 cells display selective cytotoxicity against B-cell leukemia and lymphoma. Cytotherapy. 2017;19:235-49.

170. Chu Y, Hochberg J, Yahr A, Ayello J, van de Ven C, Barth M, Czuczman M, Cairo MS. Targeting CD20+ aggressive B-cell non-Hodgkin lymphoma by anti-CD20 CAR mRNA-modified expanded natural killer cells in vitro and in NSG mice. Cancer Immunol Res. 2015;3:333-44.

171. Boissel L, Betancur M, Lu W, Krause D, Van Etten R, Wels W, Klingemann H. Retargeting NK-92 cells by means of CD19-and CD20-specific chimeric antigen receptors compares favorably with antibody-dependent cellular cytotoxicity. Oncoimmunology. 2013;2:e26527.

172. Raikar SS, Fleischer LC, Moot R, Fedanov A, Paik NY, Knight KA, Doering CB, Spencer HT. Development of chimeric antigen receptors targeting T-cell malignancies using two structurally different anti-CD5 antigen binding domains in NK and CRISPR-edited T cell lines. Oncoimmunology. 2018;7: e1407898.

173. Tassev D, Cheng M, Cheung N-K. Retargeting NK92 cells using an HLA-A2restricted, EBNA3C-specific chimeric antigen receptor. Cancer Gene Ther. 2012;19:84.

174. Sahm C, Schönfeld K, Wels WS. Expression of IL-15 in NK cells results in rapid enrichment and selective cytotoxicity of gene-modified effectors that carry a tumor-specific antigen receptor. Cancer Immunol Immunother. 2012; 61:1451-61.

175. Zhang Q, Xu J, Ding J, Liu H, Li H, Li H, Lu M, Miao Y, Wang Z, Fu Q. Bortezomib improves adoptive carbonic anhydrase IX-specific chimeric antigen receptor-modified NK92 cell therapy in mouse models of human renal cell carcinoma. Oncol Rep. 2018;40:3714-24.

176. Zhang G, Liu R, Zhu X, Wang L, Ma J, Han H, Wang X, Zhang G, He W, Wang W. Retargeting NK-92 for anti-melanoma activity by a TCR-like singledomain antibody. Immunol Cell Biol. 2013;91:615-24

177. Yu M, Luo H, Fan M, Wu X, Shi B, Di S, Liu Y, Pan Z, Jiang H, Li Z. Development of GPC3-specific chimeric antigen receptor-engineered natural killer cells for the treatment of hepatocellular carcinoma. Mol Ther. 2018;26:366-78.

178. Shiozawa M, Chang C-H, Huang Y-C, Chen Y-C, Chi M-S, Hao H-C, Chang YC, Takeda S, Chi K-H, Wang Y-S. Pharmacologically upregulated carcinoembryonic antigen-expression enhances the cytolytic activity of genetically-modified chimeric antigen receptor NK-92MI against colorectal cancer cells. BMC Immunol. 2018;19:27.

179. Chang Y-H, Connolly J, Shimasaki N, Mimura K, Kono K, Campana D. A chimeric receptor with NKG2D specificity enhances natural killer cell activation and killing of tumor cells. Cancer Res. 2013;73:1777-86.

180. Kruschinski A, Moosmann A, Poschke I, Norell H, Chmielewski M, Seliger B, Kiessling $\mathrm{R}$, Blankenstein $\mathrm{T}$, Abken $\mathrm{H}$, Charo J. Engineering antigen-specific primary human NK cells against HER-2 positive carcinomas. Proc Natl Acad Sci. 2008;105:17481-6.
181. Liu H, Yang B, Sun T, Lin L, Hu Y, Deng M, Yang J, Liu T, Li J, Sun S. Specific growth inhibition of ErbB2-expressing human breast cancer cells by genetically modified NK-92 cells. Oncol Rep. 2015;33:95-102.

182. Zhang Q, Tian K, Xu J, Zhang H, Li L, Fu Q, Chai D, Li H, Zheng J. Synergistic effects of cabozantinib and EGFR-specific CAR-NK-92 cells in renal cell carcinoma. J Immunol Res. 2017;2017:6915912.

183. Tang X, Yang L, Li Z, Nalin AP, Dai H, Xu T, Yin J, You F, Zhu M, Shen W, Chen G, Zhu X, Wu D, Yu J. Erratum: first-in-man clinical trial of CAR NK-92 cells: safety test of CD33-CAR NK-92 cells in patients with relapsed and refractory acute myeloid leukemia. Am J Cancer Res. 2018;8:1899.

184. Gonzalez-Rodriguez AP, Villa-Alvarez M, Sordo-Bahamonde C, LorenzoHerrero S, Gonzalez S. NK cells in the treatment of hematological malignancies. J Clin Med. 2019;8.

185. Grossenbacher SK, Aguilar EG, Murphy WJ. Leveraging natural killer cells for cancer immunotherapy. Immunotherapy. 2017;9:487-97.

186. D'Costa J, Mansfield SG, Humeau LM. Lentiviral vectors in clinical trials: current status. Curr Opin Mol Ther. 2009;11:554-64.

187. Kalos M, Levine BL, Porter DL, Katz S, Grupp SA, Bagg A, June CH. T cells with chimeric antigen receptors have potent antitumor effects and can establish memory in patients with advanced leukemia. Sci Transl Med. 2011; 3:95ra73.

188. Thomas CE, Ehrhardt A, Kay MA. Progress and problems with the use of viral vectors for gene therapy. Nat Rev Genet. 2003;4:346-58.

189. Sutlu T, Nystrom S, Gilljam M, Stellan B, Applequist SE, Alici E. Inhibition of intracellular antiviral defense mechanisms augments lentiviral transduction of human natural killer cells: implications for gene therapy. Hum Gene Ther. 2012:23:1090-100

190. Sim GC, Martin-Orozco N, Jin L, Yang Y, Wu S, Washington E, Sanders D, Lacey C, Wang $Y$, Vence L, Hwu P, Radvanyi L. IL-2 therapy promotes suppressive ICOS+ Treg expansion in melanoma patients. J Clin Invest. 2014;124:99-110.

191. Pedroza-Pacheco I, Madrigal A, Saudemont A. Interaction between natural killer cells and regulatory T cells: perspectives for immunotherapy. Cell Mol Immunol. 2013;10:222-9.

192. Conlon KC, Potter EL, Pittaluga S, Lee CR, Miljkovic MD, Fleisher TA, Dubois S, Bryant BR, Petrus M, Perera LP, Hsu J, Figg WD, Peer CJ, Shih JH, Yovandich JL, Creekmore SP, Roederer M, Waldmann TA. IL15 by continuous intravenous infusion to adult patients with solid tumors in a phase I trial induced dramatic NK-cell subset expansion. Clin Cancer Res. 2019;25:4945-54.

193. Waldmann TA, Lugli E, Roederer M, Perera LP, Smedley JV, Macallister RP, Goldman CK, Bryant BR, Decker JM, Fleisher TA, Lane HC, Sneller MC, Kurlander RJ, Kleiner DE, Pletcher JM, Figg WD, Yovandich JL, Creekmore SP. Safety (toxicity), pharmacokinetics, immunogenicity, and impact on elements of the normal immune system of recombinant human IL-15 in rhesus macaques. Blood. 2011;117:4787-95.

194. Conlon KC, Lugli E, Welles HC, Rosenberg SA, Fojo AT, Morris JC, Fleisher TA, Dubois SP, Perera LP, Stewart DM, Goldman CK, Bryant BR, Decker JM, Chen J, Worthy TA, Figg WD Sr, Peer CJ, Sneller MC, Lane HC, Yovandich JL, Creekmore SP, Roederer M, Waldmann TA. Redistribution, hyperproliferation activation of natural killer cells and CD8 T cells, and cytokine production during first-in-human clinical trial of recombinant human interleukin-15 in patients with cancer. J Clin Oncol. 2015;33:74-82.

195. Tugues S, Burkhard SH, Ohs I, Vrohlings M, Nussbaum K, Vom Berg J, Kulig $P$, Becher B. New insights into IL-12-mediated tumor suppression. Cell Death Differ. 2015;22:237-46.

196. Lasek W, Zagożdżon R, Jakobisiak M. Interleukin 12: still a promising candidate for tumor immunotherapy? Cancer Immunol Immunother. 2014; 63:419-35.

197. Kwilas AR, Ardiani A, Donahue RN, Aftab DT, Hodge JW. Dual effects of a targeted small-molecule inhibitor (cabozantinib) on immune-mediated killing of tumor cells and immune tumor microenvironment permissiveness when combined with a cancer vaccine. J Transl Med. 2014;12:294.

198. Patnaik A, Swanson KD, Csizmadia E, Solanki A, Landon-Brace N, Gehring MP, Helenius K, Olson BM, Pyzer AR, Wang LC, Elemento O, Novak J, Thornley TB, Asara JM, Montaser L, Timmons JJ, Morgan TM, Wang Y, Levantini E, Clohessy JG, Kelly K, Pandolfi PP, Rosenblatt JM, Avigan DE, Ye H, Karp JM, Signoretti S, Balk SP, Cantley LC. Cabozantinib eradicates advanced murine prostate cancer by activating antitumor innate immunity. Cancer Discov. 2017;7:750-65.

199. Bonifant CL, Jackson HJ, Brentjens RJ, Curran KJ. Toxicity and management in CAR T-cell therapy. Mol Ther Oncolytics. 2016;3:16011. 
200. Gross G, Eshhar Z. Therapeutic potential of T cell chimeric antigen receptors (CARs) in cancer treatment: counteracting off-tumor toxicities for safe CAR T cell therapy. Annu Rev Pharmacol Toxicol. 2016;56:59-83.

201. Tay SS, Carol H, Biro M. TriKEs and BiKEs join CARs on the cancer immunotherapy highway. Hum Vaccines Immunother. 2016;12:2790-6.

202. Harrer DC, Dorrie J, Schaft N. Chimeric antigen receptors in different cell types: new vehicles join the race. Hum Gene Ther. 2018;29:547-58.

\section{Publisher's Note}

Springer Nature remains neutral with regard to jurisdictional claims in published maps and institutional affiliations. 